\title{
Sustainable Development Importance in Higher Education for Occupational Health and Safety Using Egypt Vision 2030 under COVID-19 Pandemic
}

\author{
Tarek Adel Mouneer ${ }^{(1)}$ \\ Mechanical Engineering Department, Benha Faculty of Engineering, Benha University, Benha, Egypt \\ Email: tarek.mouneer@bhit.bu.edu.eg, tarekadel2004@yahoo.com
}

How to cite this paper: Mouneer, T. A. (2021). Sustainable Development Importance in Higher Education for Occupational Health and Safety Using Egypt Vision 2030 under COVID-19 Pandemic. Journal of Geoscience and Environment Protection, 9, 74-112.

https://doi.org/10.4236/gep.2021.94006

Received: March 12, 2021

Accepted: April 17, 2021

Published: April 20, 2021

Copyright $\odot 2021$ by author(s) and Scientific Research Publishing Inc. This work is licensed under the Creative Commons Attribution International License (CC BY 4.0). http://creativecommons.org/licenses/by/4.0/ Open Access

\begin{abstract}
Insertion of Sustainable Development Goals (SDGs) into higher education is an important concern. This article aims to address the influences of SDGs in higher and engineering educational system in Egypt. The present study focuses on SDGs 3, 4, 6, 7, 9, and 11. SDG 3 is related to occupational health and SDG 4 is related to higher education development. However, SDGs 6, 7, 9 , and 11 are related to both mechanical and environmental engineering, and occupational safety. The study approach involves case risk analysis, investigations, and review for design concepts of occupational health and safety before and after the Coronavirus disease (COVID-19). A number of cross-sectional studies that constitute 125 multidisciplinary research plans (MDRPs) are grouped to monitor and evaluate two main factors which are an influence of involving SDGs into engineering education and selected curriculum of occupational health and safety. Then the results of these research-based studies, which performed over four academic years started from 2017 up to date 2021, are depicted and discussed. These results reveal the importance of interlink between engineering education and the intended SDGs. The latest 25 MDRPs demonstrate that Egypt response to alleviate the COVID-19 is rapidly pronounced specially on SDGs 3 and 4 simultaneously. However, those MDRPs show that neither record impacts nor delays on SDGs 6, 7, 9 and 11. The conclusions prioritize both the advanced educational mechanisms and verify the engineering curriculums to raise awareness of SDGs among both staff members and students in Egyptian universities. Finally, future work is recommended at the end of this article to focus on each specific goal to gain deep insight to state of the art for each SDG around globe using education development.
\end{abstract}




\section{Keywords}

Sustainable Development, Education Development, Occupational Safety, Occupational Health, Egypt Vision 2030, COVID-19 Pandemic

\section{Introduction}

Early on 25th September 2015, the United Nations (UN) presented Sustainable Development Goals (SDGs) to be achieved within the bounded time frame of fifteen years, starting from 1st January 2016 until 31st December 2030. The SDGs can be classified into social, economic, and environmental goals. The 2030 Agenda is a set of 17 Sustainable Development Goals (SDGs) with 169 targets stimulating actions to shift the world onto a sustainable and resilient path. The SDGs have been classified by different research interests, vision, mission, and researcher's perspectives, as reported by Giannetti et al. (2020). This classification of SDGs is presented by many studies based on their objectives on social basis, economic basis, and environment basis. The SDGs have their impacts on all humanitarian fields such as combating poverty (SDG 1) and hunger (SDG 2), raising the quality of education (SDG 4), gender equality (SDG 5), reducing differences between the spectrums of society (SDG 10), divulging peace and justice (SDG 16), and in practice areas that include water conservation and purity (SDG 6 ), the use of clean energies (SDG 7), developing industry and infrastructure (SDG 9), establishing smart cities and societies (SDG 11), rotating responsible production (SDG 12), preserving the climate (SDG 13), underwater life (SDG 14) and above the earth (SDG 15).

Firstly, the socially oriented SDGs are considered as the set of SDGs \# 1, 3, 4, $6,11,16$, and 17. Each of these SDGs has a number of social, economic and environmental targets. The targets for SDG 1 consist of 1 economic target plus 6 social targets. For SDG 3, the targets consist of 13 social targets, however, SDG 4 consists of 10 social targets, and for SDG 6 consists of 5 social targets plus 3 environmental targets. Meanwhile, SDG 11 consists of 2 economic targets plus 8 social targets and 2 environmental targets, and SDG 16 consists of 12 social targets, and SDG 17 consists of 9 economic targets plus 10 social targets. Secondly, the economically oriented SDGs are considered as the set of SDGs 2, 7, 8, 9, and 10. The targets of SDG 2 consist of 5 economic target plus 3 social targets, and the targets of SDG 7 consists of 4 economic targets plus 1 social target. On the other hand, the targets of SDG 8 consist of 8 economic targets plus 2 social targets, and the targets of SDG 9 consist of 7 economic targets plus 1 social target. However, the targets of SDG 10 consist of 8 economic targets plus 2 social targets. Thirdly, the environmental oriented SDGs are the set of SDGs 12, 13, 14, and 15. The targets of SDG 12 consist of 1 economic target, 2 social targets and 8 environmental targets, however, SDG 13 consists of 1 economic target plus 4 environmental targets. SDG 14 consists of 2 economic targets plus 8 environmental 
targets, meanwhile SDG 15 consists of 2 economic targets, 2 social targets and 3 environmental targets. Similarly, Egypt vision 2030 reflects the three dimensions of sustainable development: economic, social, and environmental dimensions.

Recently, many publications focus on the importance of these SDGs and their prioritization among different countries (Cernev and Fenner, 2020; Moyer and Hedden, 2020). Modeling and measuring techniques were varied using many approaches to assess these SDGs and their direct and indirect impacts on most environmental applications. The available studies are focused on Agriculture and on Engineering as reported by Biemans and Siderius (2019), and by Esmaeilian et al. (2018), respectively. Besides, several studies are found on Energy by Adenle (2020), on Mining by Cole and Broadhurst (2021). Besides, recent studies conducted on waste handling by Lima et al. (2021) and Blue Economy (BE) by Lee et al. (2020). Several researches focused on socio-economical fields such as poverty-fighting (Benevenuto and Caulfield, 2019), zero hunger (Dhahri and Omri, 2020), well-being and good health (Solís et al., 2018), and gender equality (Monteiro et al., 2019). A set of monitoring indicators were established and used to perform the necessary assessment into case studies selected carefully in this researches.

\subsection{Egypt Policy for the 2030 Agenda}

More recently, the 2030 Agenda for sustainable development was adopted by world leaders. At its core are the seventeen SDGs, which are an urgent call for action by both developed countries and developing countries in a global partnership. Egypt vision 2030 is a national agenda launched in February 2016 that reflects the state's long-term strategic plan to achieve sustainable development principles and objectives in all areas. Egypt vision 2030 explores significance for addressing the impacts of climate change through an integrated and sustainable ecosystem that enhances resilience and ability to face natural hazards. The vision also focuses on the governance of state institutions and society through administrative reform, consolidating transparency, support for monitoring and evaluation systems and empowerment of local administrations. Figure 1 demonstrates the SDGs presented early on 25th September 2015, by the UN, to be achieved within the bounded time frame of fifteen years, starting from 1st January 2016 until 31st December 2030. Figure 1 illustrates that these SDGs should be carefully handled and highlighted by educational systems starting from schools and universities. Figure 1 displays randomly selected applications on most SDGs such as 2, 3, 4, 6, 7, 9, 11, and 12 which are in progress in Egypt as per both the 2030 Agenda and Egypt vision 2030. More recently, the United Nations in Egypt (Union, 2020) developed the Country Preparedness and Response Plan (CPRP) to respond to the health crisis and to cover the prosperity health-related aspects for an initial 3-month period, starting from $1^{\text {st }}$ April to $30^{\text {th }}$ June 2020 , and is adjusted as required based on the changing People situation. Figure 1 displays a graphical abstract for the present work demonstrated in this article. 

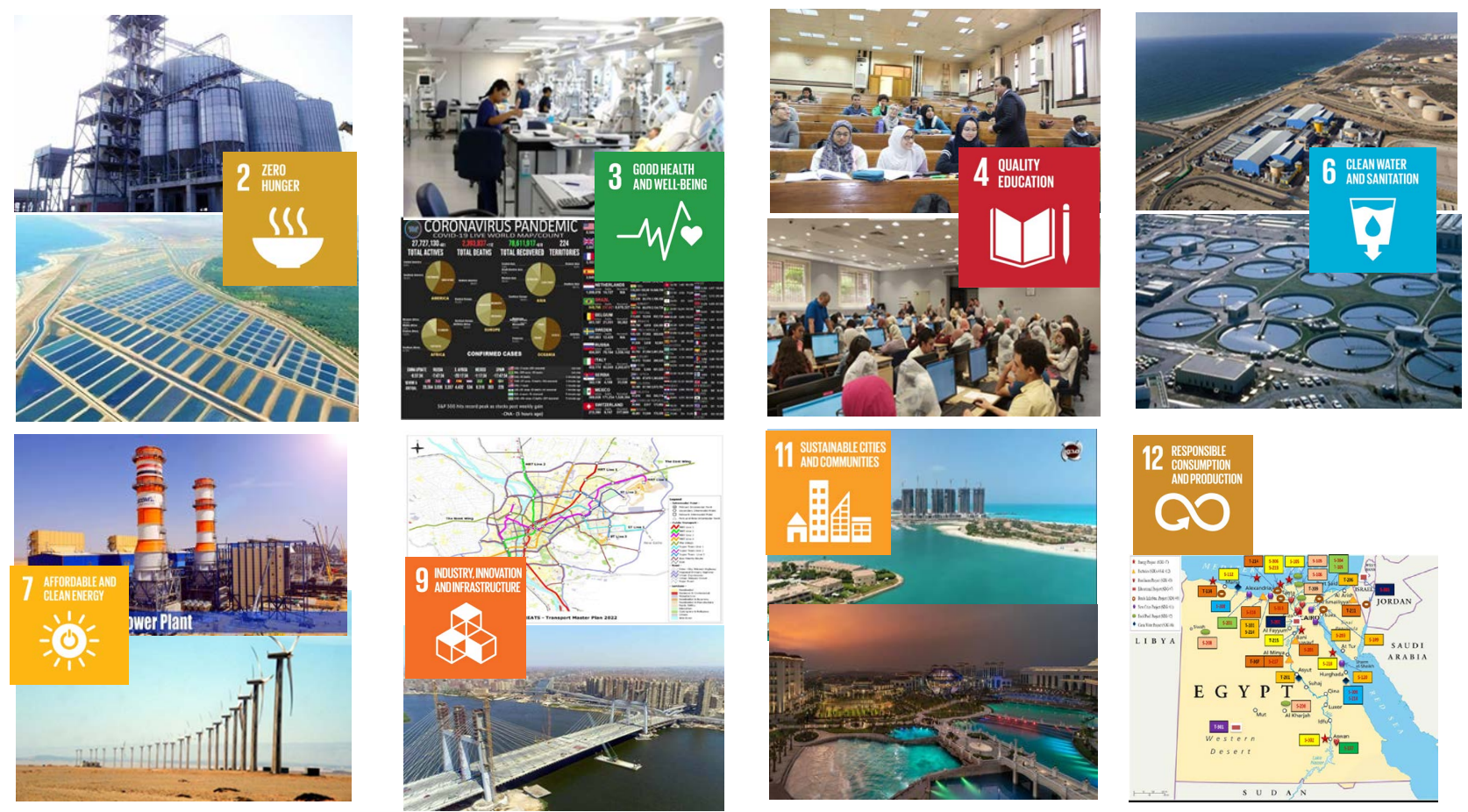

Figure 1. The 17 sustainable development goals (SDGs) and applications on some SDGs in Egypt.

\subsection{Literature Review}

Recent years have seen publication of studies providing insights of SDG 2 by many researchers to develop the Agrochemical industry. Most of these researches present how to help the crop production process (O'Riordan, 2018), and how to maximize effectiveness of land use options and strategies (Heck et al., 2018). Herrmann and Rundshagen (2020) presented a paradigm shift to investigate the implement SDG 2, by applying a humanistic management lens on the end-use of future leaders. Nikkhah and Van Haute (2020) studied the energy flow modeling and optimization trends for the food supply chain. More recently Costantini and Bacenetti (2021) investigate the environmental impact linked to agriculture production of some crops such as maize and soybean in subtropical South American, at eastern Paraguay. They adopted life cycle assessment (LCA) in a cradle-to-farm gate perspective to evaluate eight different impact categories. On the other side, some studies focus on SDG 3. Solís et al. (2018) stress the importance on open mapping for malaria presentation in some African countries. Asi and Williams (2018) investigate on the role of digital health in making progress toward SDG 3 in conflict-affected populations. Several researches focused on SDG 4 of quality education by assessing many developed methods in education and higher education, and to assess the importance of including sustainability education by developing curriculums of all disciplines especially for medicine, agriculture, sciences and engineering students (Perez-Foguet and Lazzarini, 2019). Marshall (2018) explored the religious dimensions as global education challenges. Recently, Tasdemir and Gazo (2020) recommended inte- 
grating sustainability into higher education curriculum through a transdisciplinary perspective. Priyadarshini and Abhilash (2020) suggest Introducing sustainability science in Indian universities to attain UN-Sustainable Development Goals (UNSDGs).

Many researchers conducted their studies on SDG 6 due to the importance of this SDG and its direct and indirect impacts on other SDGs. Biemans and Siderius (2019) studied hydrology effects on crop production to enhance the food production process. They proposed utilizing water sources required for enhancing the hydrology-crop relationship. Requejo-Castro et al. (2020) presented data-driven Bayesian network modeling to explore the relationships between SDG 6 and UNSDG 2030 Agenda. On the other hand, many researchers conducted their studies on clean and drinking water (Postigo and Richardson, 2019), wastewater (Lekomo et al., 2021), storm water, and sanitation. Delre et al. (2019) measure the site-specific carbon footprints of Scandinavian wastewater treatment plants using the LCA approach. However, Huyghe et al. (2021) recently assess the urban water cycle and sustainability using the City Blueprint Approach (CBA). Lee et al. (2020) highlighted on the importance of the blue economy (ocean economy). Several researches were investigated on SDG 7 for clean energy resources and their opportunities in different countries such as solar energy by Adenle (2020), and wind energy by Nazir et al. (2020). Dada and Mbohwa (2018) added to these studies the opportunities of energy from waste as possible way of meeting SDG 7. O and Kim (2019) demonstrate perspective study towards achieving SDG 7 in sustainable development in Korea. Santika et al. (2019) discussed the inter-linkage between energy and SDG 7. Recently, Aziz and Chowdhury (2021) validate using solar mini-grids as solution of choice for the electrification for remote off grid communities across the globe. They stated that the studies for such mini grid are still limited. They indicate the effects of uncontrollable factors like solar irradiation, solar panel efficiency, panel cost, land cost and solar home system. Maji and Adamu (2021) investigate the impact of removable energy consumption on sectorial environmental quality in the presence of governed effectiveness in Nigeria. They conclude that renewable energy consumptions have a favorable impact on the environmental quality of the transportation sector, residential and non-residential buildings in both commercial and public sectors.

In contrast to this extensive literature, very few studies have been conducted to study SDG 9 and its relationship with occupational health and safety. Recently, Alawneh et al. (2019) discuss the global urban development Agenda focusing on SDG 9. Kynčlová et al. (2020) introduced the SDG 9 index as a measure of the country's progress towards achieving industry-related targets of SDG 9. Parnell (2016) assessed the integrating of SDGs into the sustainable nonresidential building focusing on SDG 11. Acuti et al. (2020) investigate a theoretical framework of urban resilience to provide new insights into the contribution. Omer and Noguchi (2020) introduced conceptual framework for understanding the 
direct position contribution of building materials in the achievement of SDGs $11,3,7,9,12,13$, and 15 addition of the invisible contributions on SDGs 2, 5, 10, and 16. Reyes et al. (2014) investigated health and safety criteria for determining the sustainable value of construction projects. Lu et al. (2020) investigates sustainable development performance in the electrical wire and cable industry by applying the integrated fuzzy approach. Cormier and Elliott (2017) conducted a study on SDG 14 for life below water using SMART marine goals, as targets and management. Mao et al. (2019) investigate a case study of an institutional approach to achieve proper control of coastal water pollution about how China realizes SDG 14 by 2030. Wang and Wu (2020) presented a safety informatics study, as a new, promising, and sustainable area of safety science in the information age for students. Athar et al. (2019) investigated an inherent safety study for the sustainable process design of process piping at the preliminary design stage.

More recently several researches focus on the SDGs after the Coronavirus disease (COVID-19) pandemic on directly affected SDGs such as SDG 3, 4, 6, 7, and 13. These studies indicate and identify the COVID-19 impacts on the 2030 agenda and necessary verifications for their concerned targets. Several studies discuss the impact of the pandemic on both SDGs 3 and 4. Recently, a very important research is conducted on the impact of non-pharmaceutical interventions (NPIs) to reduce the COVID-19 mortality and healthcare demand. They carefully proposed and highly recommended two mechanisms in their study to reduce by two short-term strategies by mitigation and suppression. More recently Rowan and Moral (2021) investigate disposable face masks and reusable face coverings as non-pharmaceutical interventions (NPIs) to prevent transmission of SARS-CoV-2 variants that cause COVID-19. Their study is a role of new sustainable NPI design innovations and predictive mathematic. Villalba and Useche (2021) recommend using methodological approach for the construction of environmental management indicators in universities. It's focused on mental health difficulties among students in Bangladeshi. Mishra et al. (2020) explored the effects of outline teaching-learning mechanism in higher education during lockdown period of COVID-19 pandemic in India. They seek to address the requested essentialities of online teaching-learning in education amid the COVID-19 pandemic. Elsheikh et al. (2021) investigate model on deep learning-based forecasting for COVID-19 outbreak in Saudi Arabia. Farkas et al. (2020) investigate the potential of wastewater surveillance for monitoring the COVID-19.

Only few researches stress the important of SDGs 2 and 7 during the COVID-19 pandemic. Haq et al. (2021) add to these studies on SDG 7 that the borehole thermal energy system is an important component of the future low temperature heating networks in Finland. They investigated the mobility of borehole thermal energy system from solar assisted storage to industrial excess heat storage. Ruan et al. (2021) state that the data developed to substantiate the pandemic impacts such as electrical system security, electrical power demand, electrical power generation, and electricity prices. They conclude that geographically 
diverse impacts over observed and quantified the bulk power systems in US market in the north east region are the most affected. Zhou et al. (2020) focus on the impact of the COVID-19 on SDG 2 by reviewing the vegetable supply chain in China. These findings prove that farmer household participation in local market and modern markets methods helps mitigate the negative effects of the COVID-shock. Du et al. (2020) study impacts of the COVID-19 pandemic on family farms in Chin at the short- and long-term from a survey of 2324 farms. Djekic et al. (2021) suggest to provide an important insight into the response of food safety systems at the first months of pandemic. Othman and Latif conduct mitigation measures and focus on control strategies for SDG 13 relating to the COVID-19 in Malaysia. They conclude that the reduction of human activities significantly reduces air pollution and improves human health.

Since the literature review showed no comprehensive study on the SDGs and how to implement them into higher education in Egypt and their direct and indirect relationship to occupational health and safety before and after COVID-19 and its impacts and country response, the present paper aims to assess and evaluate the results of many cross-sectional studied to fill the knowledge gap in importance of highlighting on SDGs and the 2030 Agenda in higher education in Egypt before and under COVID-19 pandemic.

\subsection{Research Objectives}

The overall objective of this research is to demonstrate the results of the cross-sectional study for research-based learning methodology prepared by multi-disciplinary students' groups applied on occupational safety and health courses in engineering education over four academic years and by focusing on relevant SDGs. Specific objectives are to assess the effectiveness of research-based learning method for occupational safety and health course, to assess the effect of forming multi-disciplinary workgroup on the successful interactions between students, to assess the importance of implementing sustainable development goals in engineering education between both students and staff members, and finally to demonstrate the influence of the COVID-19 on research projects topics before and after this pandemic.

\section{Methodology}

The research methodology aims to present a comprehensive investigation on the performed cross-sectional studies for the deep understanding of industrial safety objectives and regulations of construction projects and Industries currently in Egypt vision 2030, either on short-term strategies over a period of 3 - 5 years, or on long-term strategies over a period of 10 - 15 years, up to 2030. The Egyptian universities (EUs) role should be adapted carefully to interlink between the country's mission and its impacts on scientific and humanistic sciences in higher education. The current research reviews the investigations prepared by second-year engineering students in the Faculty of Engineering, in Benha University (BU) over recent four academic years from of the Fall 2017 semester to the Fall 2020 
semester. It should be clear that these investigations promote a positive culture to disseminate the SDGs importance. The author has requested all students to prepare their studies using data collected from Egypt's current projects to monitor and evaluate the meeting of the most relevant SDGs highlighted in the 2030 Agenda and under the COVID-19 pandemic. Then, all of presented cross-sectional case studies were performed under author supervision, technical support, and guidance. The students were assigned and grouped into moreover 119 multi-disciplinary research projects (MDRP) groups.

\subsection{Students Grouping Method}

The literature review includes several researches explored the effects of outline teaching-learning mechanism in higher education during lockdown period of COVID-19 pandemic in many countries (Villalba and Useche, 2021; Mishra et al., 2020). However, Killian et al. (2019) suggest to group undergraduate students in teams to study the SDGs applications. Similarly, this paper presents newest method from several MDRPs group. Each group was joined by 15 team members of students such as 5 students of mechanical engineering, 5 students of electrical engineering, and 5 students of civil engineering students. Then, a numbering system was established and used to assign, number and detect the group details. Table 1 depicts the numbering systems followed regularly over four academic years started from the Fall 2107 to the Fall 2021. Table 1 shows 35 MDRPs were in 2017/2018, which were tagged as S-100s groups (S indicates for Sunday's groups), and T-100s groups (T indicates for Tuesday's groups). Table 1 shows also 34 MDRPs performed in 2018/2019, which were tagged as S-200s and T-200s groups. Table 1 shows 25 MDRPs performed recently in 2019/2020, which were tagged as S-300s and T-300s groups. More recently, 25 MDRPs performed in 2020/2021, were tagged as ST-400s groups, are shown in Table 1.

\subsection{Classification of MDRPs on SDGs}

In this article, the performed MDRPs are classified according to three groups of

Table 1. Numbering systems and characteristics for MDRPs over four academic years started from the Fall 2107 to the Fall 2021.

\begin{tabular}{|c|c|c|c|c|c|c|}
\hline $\begin{array}{c}\text { MDRPs } \\
\text { Numbering } \\
\text { System }\end{array}$ & $\begin{array}{l}\text { MDRPs } \\
\text { range }\end{array}$ & Academic years & $\begin{array}{l}\text { Number } \\
\text { Of MDRPs }\end{array}$ & $\begin{array}{c}\text { Total } \\
\text { Number } \\
\text { Of Students }\end{array}$ & $\begin{array}{c}\text { SDGs } \\
\text { Applied }\end{array}$ & $\begin{array}{c}\text { COVID-19 } \\
\text { Applied }\end{array}$ \\
\hline $\begin{array}{l}\text { S-100s } \\
\text { T-100s }\end{array}$ & $\begin{array}{l}\text { S-101 to S-119, } \\
\text { T-101 to T-116 }\end{array}$ & $2017 / 2018$ & $\begin{array}{l}19 \\
16\end{array}$ & 385 & No & No \\
\hline $\begin{array}{l}\text { S-200s } \\
\text { T-200s }\end{array}$ & $\begin{array}{l}\text { S-201 to S-219, } \\
\text { T-201 to T-215 }\end{array}$ & $2018 / 2019$ & $\begin{array}{l}19 \\
15\end{array}$ & 506 & Yes & No \\
\hline $\begin{array}{l}\text { S-300s } \\
\text { T-300s }\end{array}$ & $\begin{array}{l}\text { S-301 to S-314, } \\
\text { T-301 to T-311 }\end{array}$ & $2019 / 2020$ & $\begin{array}{l}14 \\
11\end{array}$ & 435 & Yes & No \\
\hline ST-400s & ST- 401 to ST- 425 & $2020 / 2021$ & 25 & 376 & Yes & Yes \\
\hline
\end{tabular}


SDGs; which can be listed as follows: 1) Group I for MDRPs focused on SDGs 2, 3, and 4 (Table 2), 2) Group II for MDRPs focused on SDGs \#6, and \#7 (Table 2),

Table 2. MDRPs focused on SDGs 2, 3, and 4 and relevant to SDGs 13, 14, and 15.

\begin{tabular}{|c|c|c|c|}
\hline SDG \& Logo & MDRPs & $\begin{array}{l}\text { SDG Targets \& } \\
\text { Indicators }\end{array}$ & References \\
\hline $\begin{array}{c}\text { SDG } 2 \\
\text { Zero }\end{array}$ & \multirow[b]{2}{*}{$\begin{array}{l}\text { S-105, S-106, } \\
\text { S-114, T-209 } \\
\text { ST-413 }\end{array}$} & \multirow[b]{2}{*}{$\begin{array}{c}\text { 2.1, 2.2, 2.3, 2.4, 2.5, } \\
\text { 2.A, 2.B, 2.C }\end{array}$} & \multirow[b]{2}{*}{$\begin{array}{c}\text { O’Riordan (2018) } \\
\text { Heck et al. (2018) } \\
\text { Herrmann \& Rundshagen (2020) } \\
\text { Costantini \& Bacenetti (2021) }\end{array}$} \\
\hline 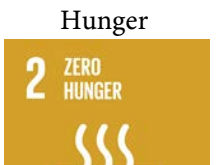 & & & \\
\hline $\begin{array}{l}\text { SDG } 3 \\
\text { Good Health \& } \\
\text { Well-Being }\end{array}$ & \multirow{2}{*}{$\begin{array}{l}\text { S-107, S-204, } \\
\text { S-206, S-305, } \\
\text { T-115, T-204, } \\
\text { T-213, T-305 } \\
\text { ST-402, ST-403 } \\
\text { ST-405, ST-410 } \\
\text { ST-412, ST-416 } \\
\text { ST-420, ST-421 } \\
\text { ST-423, ST-425 }\end{array}$} & \multirow[b]{2}{*}{$\begin{array}{c}3.1,3.2,3.3,3.4,3.5 \\
3.6,3.7,3.8,3.9 \\
3 . \mathrm{A}, 3 . \mathrm{B}, 3 . \mathrm{C}, 3 . \mathrm{D}\end{array}$} & \multirow[b]{2}{*}{$\begin{array}{c}\text { Solís et al. (2018) } \\
\text { Asi \& Williams (2018) }\end{array}$} \\
\hline 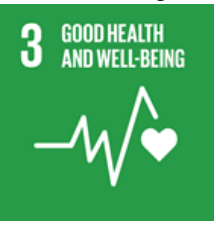 & & & \\
\hline $\begin{array}{l}\text { SDG } 4 \\
\text { Quality Education } \\
4 \text { QUALITY } \\
\text { EDUCATION }\end{array}$ & $\begin{array}{l}\text { S-204, S-206, } \\
\text { S-210, S-211, } \\
\text { S-216, T-204, } \\
\text { T-304, ST-408 } \\
\text { ST-414, ST-415 } \\
\text { ST-417, ST-419 } \\
\text { ST-423, ST-425 }\end{array}$ & $\begin{array}{c}\text { 4.1, 4.2, 4.3, 4.4, 4.5, } \\
\text { 4.6, 4.7, } \\
\text { 4.A, 4.B, } 4 . \mathrm{C}\end{array}$ & $\begin{array}{c}\text { Filho et al. (2019) } \\
\text { Perez-Foguet \& Lazzarini (2019) } \\
\text { Esmaeilian et al. (2018) } \\
\text { Priyadarshini \& Abhilash (2020) } \\
\text { Marshall (2018) } \\
\text { Villalba \& Useche (2021) }\end{array}$ \\
\hline $\begin{array}{l}\text { SDG } 13 \\
\text { Climate } \\
\text { Action }\end{array}$ & & & \\
\hline 13 CLIMATE & & $13.1,13.3,13 . \mathrm{B}$ & Athar et al. (2019) \\
\hline $\begin{array}{c}\text { SDG } 14 \\
\text { Life below Water }\end{array}$ & & & \\
\hline 14 LIFE BELOW & S-106, T-102 & $\begin{array}{l}14.1,14.2,14.4 \\
14.5,14.6,14 . b\end{array}$ & $\begin{array}{l}\text { Cormier \& Elliott (2017) } \\
\text { Mao et al. (2019) }\end{array}$ \\
\hline $\begin{array}{c}\text { SDG } 15 \\
\text { Life on Land }\end{array}$ & & & \\
\hline 15 LIFE & $\begin{array}{c}\text { S-208, S-312, } \\
\text { T-306 }\end{array}$ & $\begin{array}{c}15.1,15.2,15.3 \\
15.5,15.6\end{array}$ & Rezaian \& Jozi (2012) \\
\hline
\end{tabular}


and 3) Group III for MDRPs focused on SDGs 9, 11 and 12 (Table 3). Group I focused on SDG 2 by studying food engineering processes, food security projects, and food production factories. Group I focused on SDG 3 by investigating

Table 3. MDRPs focused on SDGs 6, 7, 9, 11 and 12.

\begin{tabular}{|c|c|c|c|}
\hline SDG \& Logo & MDRPs & $\begin{array}{l}\text { SDG Targets \& } \\
\text { Indicators }\end{array}$ & References \\
\hline $\begin{array}{c}\text { SDG } 6 \\
\text { Clean Water } \\
\text { \& Sanitation } \\
6 \text { GIEANWAIER } \\
\text { ANDSANITATION }\end{array}$ & $\begin{array}{c}\text { S-218, S-308, } \\
\text { T-201, T-205, } \\
\text { T-302 }\end{array}$ & $\begin{array}{l}6.1,6.2 \\
6.3,6.4 \\
6 . \mathrm{A}, 6-\mathrm{B} .\end{array}$ & $\begin{array}{c}\text { Lee et al. (2020) } \\
\text { Lekomo et al. (2021) } \\
\text { Huyghe et al. (2021) } \\
\text { Biemans \& Siderius (2019) } \\
\text { Requejo-Castro et al. (2020) } \\
\text { Delre et al. (2019) }\end{array}$ \\
\hline 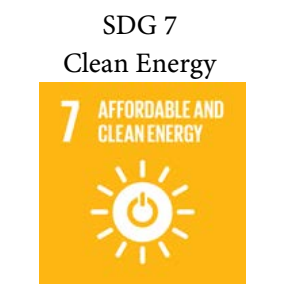 & $\begin{array}{l}\text { S-112, S-218 } \\
\text { S-302, S-306 } \\
\text { T-214, T-311 } \\
\text { ST-402 }\end{array}$ & $\begin{array}{l}\text { 7.1, 7.2, } \\
7.3,7.4 \\
\text { 7.A, 7.B }\end{array}$ & $\begin{array}{c}\text { Adenle (2020) } \\
\text { Haq et al. (2021) } \\
\text { Maji \& Adamu (2021) } \\
\text { Dada and Mbohwa (2018) } \\
\text { O \& Kim (2019) } \\
\text { Santika et al. (2019) } \\
\text { Aziz \& Chowdhury (2021) }\end{array}$ \\
\hline $\begin{array}{c}\text { SDG } 9 \\
\text { Industry, Innovation, \& } \\
\text { Infrastructure } \\
9 \text { NDUSIRY,WNOVATION } \\
\text { ANDINRASTRUGURE }\end{array}$ & $\begin{array}{l}\text { S-103, S-109, } \\
\text { S-111, S-113, } \\
\text { S-212, S-210, } \\
\text { S-304, S-307, } \\
\text { S-310, S-313, } \\
\text { T-109, T-114, } \\
\text { T-116, T-202, } \\
\text { T-205, T-208, } \\
\text { T-212, T-306 } \\
\text { ST-406, ST-409, } \\
\text { ST 422, ST-424 }\end{array}$ & $\begin{array}{l}9.1,9.2 \\
9.3,9.5 \\
9-B, 9-C\end{array}$ & Alawneh et al. (2019) \\
\hline 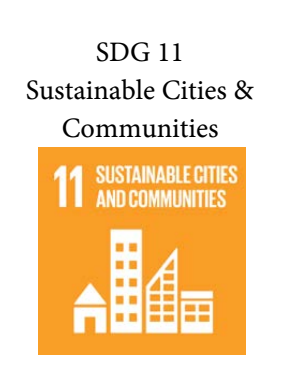 & $\begin{array}{l}\text { S-110, S-201, } \\
\text { S-203, S-207, } \\
\text { S-209, S-214, } \\
\text { S-301, T-214, } \\
\text { T-206, T-212, } \\
\text { T-214, T-215, } \\
\text { T-101, T-114, } \\
\text { T-116, ST-404, } \\
\text { ST-407, ST-408, } \\
\text { ST-411, ST-424 }\end{array}$ & $\begin{array}{l}11.2,11.3,11.4 \\
11.5,11.7,11-\mathrm{A}\end{array}$ & $\begin{array}{c}\text { Parnell (2016) } \\
\text { Acuti et al. (2020) } \\
\text { Omer \& Noguchi (2020) } \\
\text { Reyes et al. (2014) }\end{array}$ \\
\hline $\begin{array}{l}\text { SDG } 12 \\
\text { Responsible } \\
\text { Consumption } \\
\text { \& Production } \\
12 \text { RESPONSIBIE } \\
\text { GONSUMPION } \\
\text { ANDPRODUGTON }\end{array}$ & $\begin{array}{l}\text { T-116, T-210, } \\
\text { T-211, ST-418 }\end{array}$ & $\begin{array}{c}12.1,12.2,12.3 \\
12.4,12.5,12.6 \\
12.7,12.8,12-\mathrm{A} \\
12-\mathrm{B}, 12-\mathrm{C}\end{array}$ & $\begin{array}{l}\text { Hsu et al. (2021) } \\
\text { Lima et al. (2021) } \\
\text { Lu et al. (2020) }\end{array}$ \\
\hline
\end{tabular}


healthcare facilities, and medical informatics importance before and after the COVID-19 pandemic. Group I focused also on SDG 4 by studying electronic learning processes (E-Learning and On-line Learning) compared to traditional face-to-face learning processes, hybrid educational systems under COVID-19 pandemic, and advanced learning techniques, and their impact on awareness of SDGs. Group II focused on SDG 6 by studying clean water projects, water desalination projects, and sanitation projects. Group II focused on SDG 7 by investigating clean energy projects, renewable energy projects, and energy-saving techniques. However, Group III focused on SDG 9 by studying transportation projects, infrastructural projects, and their impacts on other SDGs. Group III focused on SDG 11 by studying new cities and communities, and the sustainability importance in residential and non-residential buildings. Table 2 shows the MDRPs applied on SDGs 2, 3, and 4 to indicate the performance of these current studies, and how the second-year students monitored the applications on these SDGs and targets on their selected case studies of food, healthcare, and educational projects in Egypt vision 2030. Table 2 classifies also the MDRPs applied on SDGs 6 and 7 to indicate the performed studies of clean water and clean energy projects in Egypt vision 2030. Table 2 depicts the relation between the applied MDRPs with SDGs 13, 14, and 15 to indicate their relevance with Egypt vision 2030. Table 3 depicts the MDRPs applied on SDGs 9, 11 and 12 to indicate the performed studies, on these SDGs and targets with good agreement with Egypt vision 2030. Figure 2 presents the development of summative exams through the period from Fall 2017 to Fall 2020, using multi response questions, open response questions, and hot spot questions.

\section{Results}

This section demonstrates the results of MDRPs using mapping systems, besides their classification on SDGs. These results appraise the Egypt 2030 vision. The results explore the cross-sectional studies to identify their impacts among students in Egyptian universities. The distribution of MDRPs is presented on the Egypt full map, and on enlarged maps for the greater Cairo zone map and new Capital zone. The discussion of these results is followed later in section 4 to assess the impacts of using research-based learning methodology, to evaluate the necessary modifications based on the results and the feedback from students.

\subsection{Distribution of the Current MDRPs on Egypt Maps}

Figure 3(a) portrays distribution of several MDRPs on Egypt full map after the data reduction process. As can be seen in Figure 3(a) that mega construction and industrial projects listed in Egypt vision 2030 are located on several zones such as; 1) Cairo, New Cairo, and Giza zones; 2) Suez Canal zone; 3) North Delta zone; 4) North coast zone; 5) Sinai and the Red Sea zones; 6) Upper Egypt zones and Aswan city; and 7) Western desert. Figure 3(b) presents the distribution of MDRPs located in Cairo zone. Figure 3(b) shows Cairo regional ring road which 
Benha University

Benha Faculty of Engineering

Mechanical Engineering Department January 2018

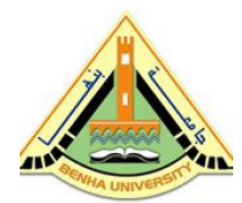

Industrial Safety (HSE)

(M-1283)

$2^{\text {rd }}$ year Mechanical Dept. Students

Time : 2 hours

\section{Final Exam}

1- a) Compare between the following abbreviations and terminologies, listed in each Row from 1 to 4 , respectively, from Lists $\mathbf{A}, \mathbf{B}$, and $\mathbf{C}$, using neat sketches if needed: (3 marks)

\begin{tabular}{|c|c|c|c|}
\hline \multicolumn{2}{|r|}{$\underline{\text { List } A}$} & $\underline{\text { List B }}$ & $\underline{\text { List } C}$ \\
\hline Row \#1 & - NFPA 101. & - OSHA. & - NFPA 72. \\
\hline Row \#2 & - NFPA. & - HVAC. & - MEP. \\
\hline Row \#3 & - NFPA 70. & - NFPA 13. & - NFPA 20. \\
\hline Row \#4 & - CCTV. & - GFCIs. & - Disconnec \\
\hline
\end{tabular}

b) List the main types of Warning Signs, and State their specific objectives to enhance the industrial safety performance and promoting a positive culture in different HSE Applications. (3 marks)

\section{2- Design for Fire Water Tanks and Evacuation Plans}

A Simulation for the Evacuation Process must be periodically performed inside the Faculty Buildings. Also, A Fire pump Set complete with Fire Water Tank shall be designed to provide the fire water to the set of Fire hose cabinets distributed in different locations, as per NFPA 14. The fire pump flow can be selected to discharge $60 \mathrm{~m}^{3} / \mathrm{hr}$ (almost $250 \mathrm{GPM}$ ). You are requested to:

a) Design a fire water storage tank (volume and dimensions) to store water demand for fire pumps set, and Plot a schematic layout for this underground water tank, according to NFPA requirements. (3 Marks)

b) Propose an Evacuation Plan for any selected two fire zones in your Faculty Buildings, using neat sketches, according to NFPA 101 requirements. (3 Marks)

c)

3- Second Rameses Movement to Grand Egyptian Museum

In 2006, Arab Contractors Company have Moved Second Ramses .... From its previous location at Ramses Square to the Grand Egyptian Museum, located on Cairo-Alex Desert Road, at $\mathrm{Km}$ 28. The Movement process duration time have been selected carefully at Thursday night to Friday Sunset. The Movement Speed has been taken $18 \mathrm{Km} / \mathrm{hr}$. Figure 3-a ( Left) presents the starting of transportation process, after the Loading process of Ramses ...... into the designed Carriage. Figure 3-b (on the right), presents the photo for the Mechanical Designer of this unique process during more than last 50 years, herein Egypt. This Professional Designer, was Prof. Dr. Ahmed Hussien, Prof of Design and Production Engineering Dept. in ASU. All of Egypt has been lost him last August, when he died. You are requested to:

a) Outline the Risk Analysis performed and taken into consideration during this transportation process. (2 marks)

b) Draw an elevation by free hand sketch for Ramses II during this transportation process, as shown in Figure 4-a, which has been designed by Prof. Ahmed Hussien. (3 marks)

c) Rename the title of Figure 3-c (right), in English and/or in Arabic (1 marks)

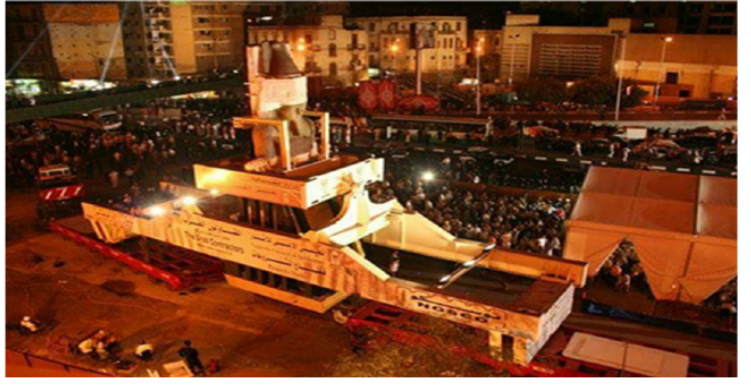

Figure 3-a: Transportation Process of Ramses II, in 2006, performed by Arab Contractors Company. (Question 4-a,b).

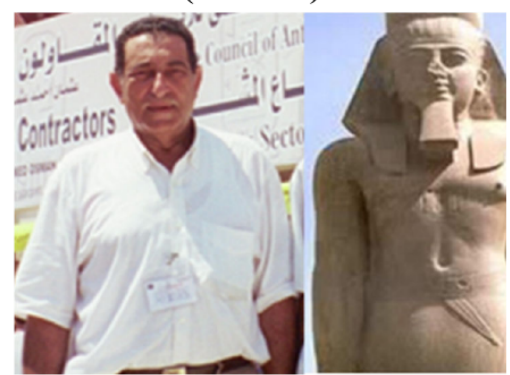

Figure 3-c: Prof. A, Hussien, and Ramses II, (Question 3-c).

Page 1 of 2 
4- Health \& Safety in New Capital (Design and Construction)

Many Projects of the New Capital in Egypt have been Established and Opened during last October victories ceremony, by the President Abdul-Fattah El-Sisi. The New Capital projects are some of the Currently Mega Projects in progress in Egypt. The new capital location has been selected carefully, as can be seen in Figure 4-c, after a lot of technical and visibility studies.

a) List six of the objectives of the New Capital, and State its Environmental added values to Egypt from point of view of Mechanical Engineers. (3 marks)

b) Outline the technical considerations to be taken from all concerned parties (Engineering Staff, Contractors, Workers, Drivers and security staff during the construction activities in New Capital Project during both Design Stage, and Construction Stage. (3 marks)

c) Redraw a free hand sketch for Figure 4-c, into your answers booklet, then Suggest and Indicate the necessary Water and Power Sources to be provided to the New Capital Zone, as per local and/or international standards and codes, based on your technical background in HSE. (3 marks)

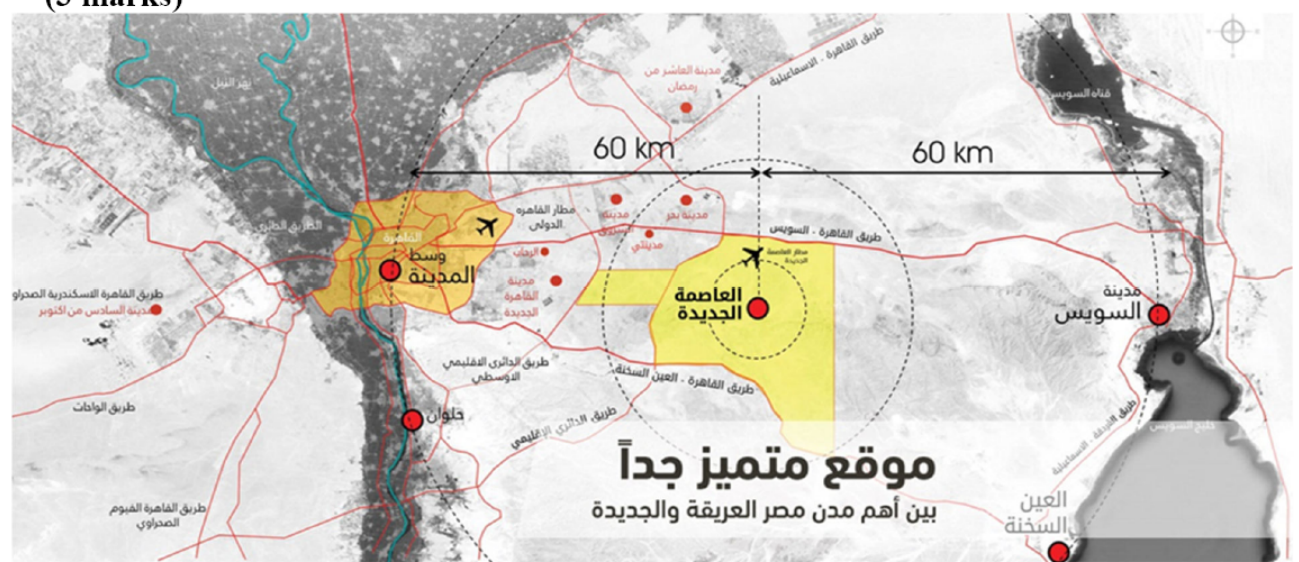

Figure 4-c: Plan view for the New Capital Location, (Question 4-c).

\section{5- Health, Safety and Environment in Mega Projects in Egypt}

Many Projects have been started recently in Egypt. A number of these Mega Projects have been selected as case study, during prepare a technical reports about different HSE Applications in Industry and Construction Activites, during current semester. Most of these reports prepared by 37 multidisciplinary groups have been investigated and prepared carefully by second year students. A selective Set have been listed and tabulated in the following Matrix, shows the areas where the case studies were applied.

a) Select Three of these projects then List the Risk analysis for each of these three Projects, and State their Principles of controls. (4 marks)

b) Plot on One Map the exact locations of these projects you have selected. (2 marks)

\begin{tabular}{|c|c|c|c|c|c|c|c|c|c|}
\hline & Selective S Groups & 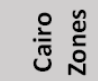 & 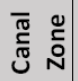 & 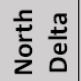 & 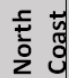 & $\vec{E}$ & 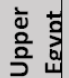 & \multicolumn{2}{|c|}{ Selective T Groups } \\
\hline S-103 & Cairo-Benha Road & $\mathbf{S}$ & & & $T$ & & & Alexandria City & T-101 \\
\hline S-105 & Silos in Dumyat & & & $\mathrm{S}, \mathrm{T}$ & & & & Burolos Power Station & T-102 \\
\hline S-106 & Ghulyon Fishes Farm & $\mathbf{T}$ & $T$ & $S, T$ & $T$ & $T$ & $T$ & Vehicles \& Roadways & T-103 \\
\hline S-107 & Magdy Yakob Center & & $T$ & & & & $\mathrm{~S}$ & Ismaalia Tunnels & T-105 \\
\hline S-109 & New Suze Canal & $T$ & $S, T$ & $T$ & $T$ & $T$ & $T$ & Radars \& Navigation & T-106 \\
\hline S-110 & New Capital Power Station & $\mathrm{S}, \mathrm{T}$ & $\mathbf{T}$ & $T$ & $T$ & $T$ & $T$ & Churches \& Masjids & T-107 \\
\hline S-111 & Rod El-Farg Axis & $\mathrm{S}, \mathrm{T}$ & $T$ & $T$ & $T$ & $T$ & $T$ & Masjids \& Churches & T-108 \\
\hline S-112 & Doher Gas Field & $\mathbf{T}$ & & $T$ & $S$ & & $T$ & Regional Ring Road & T-109 \\
\hline S-113 & Cairo Metro Lines & $S$ & & & $T$ & & & Alameen- Dabaa Road & T-114 \\
\hline S-114 & Silos and Alexandria Ports & $T$ & & & $\mathbf{S}$ & & & 57357 Hospital & T-115 \\
\hline S-119 & Old Masjids in Cairo & $\mathrm{S}, \mathrm{T}$ & & & & & & Mushir Tantawi Axis & T-116 \\
\hline
\end{tabular}

(a) 


\section{Benha University \\ Benha Faculty of Engineering} Mechanical Engineering Department January 2019

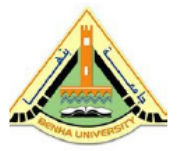

Final Exam
Industrial Safety (HSE)

(M-1283)

$2^{\text {rd }}$ year Mechanical Dept. Students

Time : 2 hours

Question 1: MCQs., True/False, and Matching Questions on Industrial Safety (HSE) (8 marks)

Question 1.1: MCQs Question (5 marks)

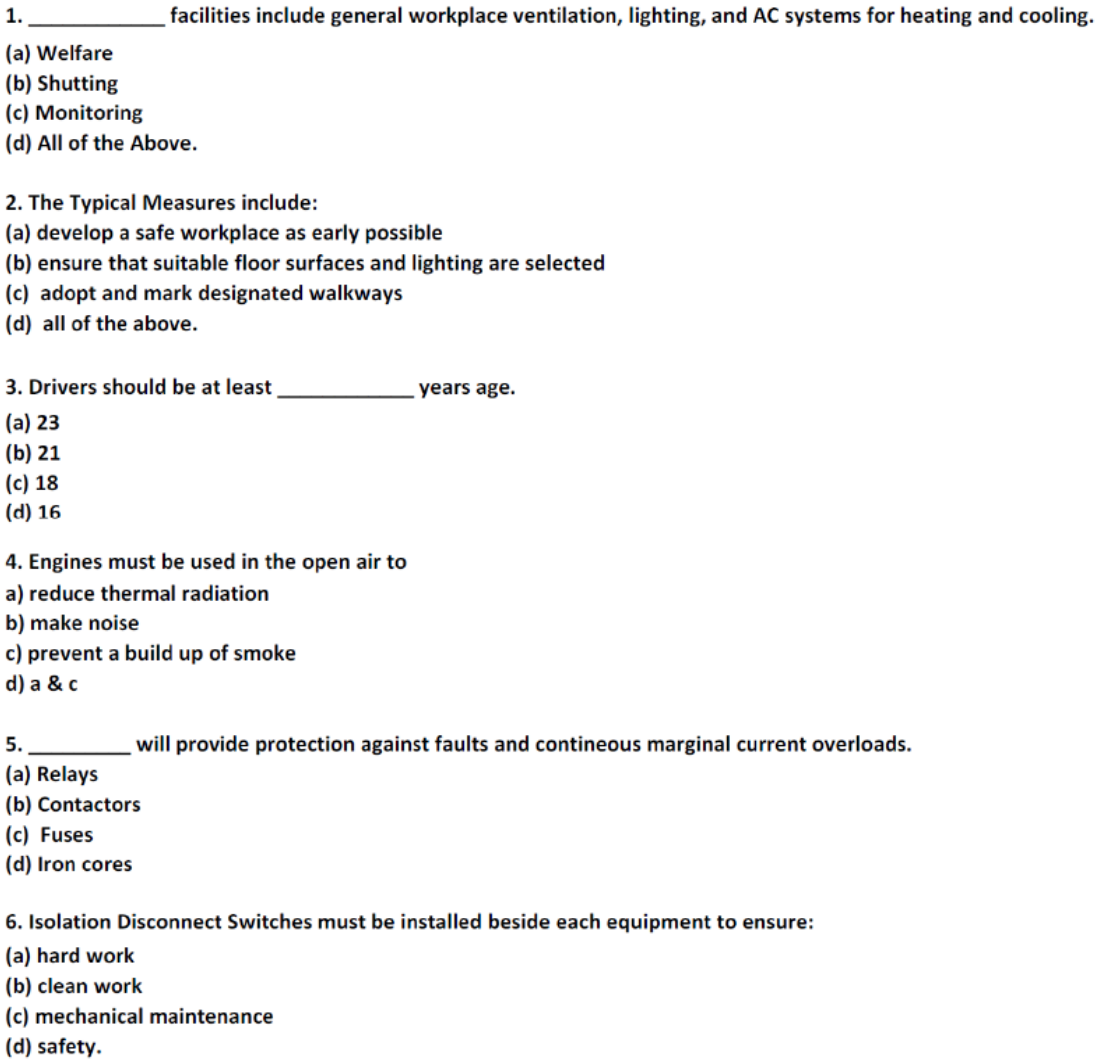

(b) 21

(c) 18

(d) 16

4. Engines must be used in the open air to

a) reduce thermal radiation

b) make noise

c) prevent a build up of smoke

d) a \& c

5. will provide protection against faults and contineous marginal current overloads.

(a) Relays

(b) Contactors

(c) Fuses

(d) Iron cores

6. Isolation Disconnect Switches must be installed beside each equipment to ensure:

(a) hard work

(b) clean work

(c) mechanical maintenance

(d) safety.

7. This warning sign is used to indicate the Eyewasher station in Chemical Factories.

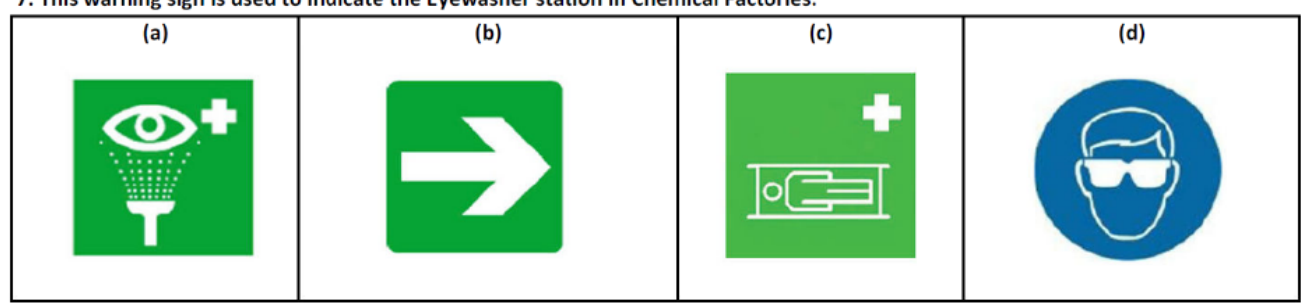

8. This warning sign is used to indicate the Fire Alarm call point inside building Floors.

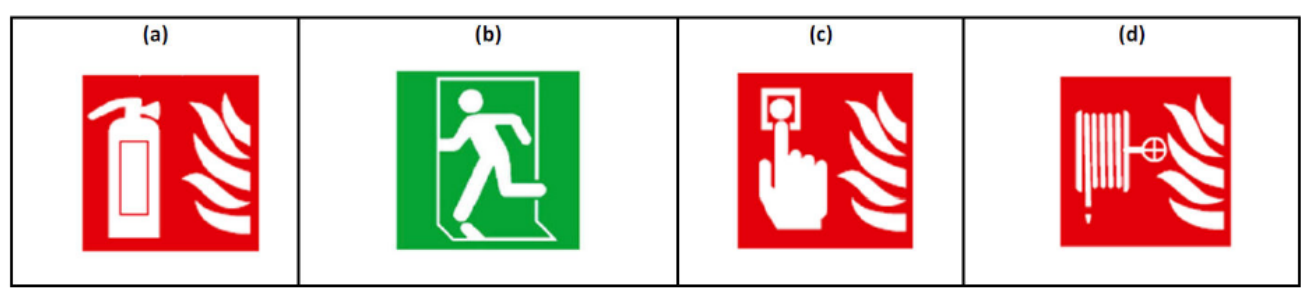

Final Exam - Industrial Safety - January 2019 (2"d year Mechanical Students)

Page 1 | 6 


\section{Benha University \\ Benha Faculty of Engineering Mechanical Engineering Department January 2019}

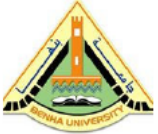

Industrial Safety (HSE)

(M-1283)

$2^{\text {rd }}$ year Mechanical Dept. Students

Time : 2 hours

Question 2 Ranking and Short Answer Questions on Industrial Safety (HSE) (10 marks) Question 2.1: Ranking Question, Select the correct Ranking for the following items (4 marks)

$\begin{aligned} & \text { 17. The Cohesive arrangement for the chapters of technical } \\
& \text { report writing are as follows: }\end{aligned}$
\begin{tabular}{|l|l|}
\hline $\begin{array}{l}\text { a) Introduction / Conclusion / Discussion / Methodology / Results } \\
\text { b) Introduction / Methodology / Results / Conslusion / Discussion } \\
\text { c) Introduction / Methodology / Results / Discussion / Conslusion } \\
\text { d) Introduction / Results / Discussion / Methodology / Conslusion }\end{array}$ \\
\begin{tabular}{|l|l|} 
18. The Logic arrangement of construction activities for any \\
new project can be listed as follows:
\end{tabular} \\
$\begin{array}{l}\text { a) Demolation / Excavation / Design / Construction } \\
\text { b) Design / Construction / Demolation / Excavation } \\
\text { c) Design / Demolation / Excavation / Construction } \\
\text { d) Demolation / Design / Excavation / Construction }\end{array}$ \\
\begin{tabular}{|l} 
19. The most important tender documents can be sorted and \\
classified as follows:
\end{tabular} \\
$\begin{array}{l}\text { 2) BoQ / Specifications / Design Drawings / Construction Drawings } \\
\text { b) Specifications / BoQ / Design Drawings / Construction Drawings } \\
\text { c) Design Drawings / Construction Drawings / BoQ / Specifications } \\
\text { d) Specifications / Design Drawings / BoQ / Construction Drawings. }\end{array}$ \\
management can be arranged as follows: & $\begin{array}{l}\text { a) Measuring Performance / Reviewing Performance / Policy / Organizing / Planning } \\
\text { b) Policy / Organizing / Planning / Measuring Performance / Reviewing Performance } \\
\text { c) Policy / Measuring Performance / Reviewing Performance / Organizing / Planning } \\
\text { d) Planning / Policy / Organizing / Measuring Performance / Reviewing Performance }\end{array}$ \\
\hline
\end{tabular}

Question 2.2: Short Answer Questions (6 marks)

For an Educational Building, a Fire pump Set complete with Fire Water Tank shall be designed to provide the fire water to the set of Fire hose cabinets distributed in different locations, as per NFPA 14. The fire pump flow has been selected to discharge $0.08 \mathrm{~m}^{3} / \mathrm{sec}$. Design the volumes of two fire water storage tanks, for $60 \mathrm{mins}$ and $90 \mathrm{mins}$ as requested in items $21 \& 23$, respectively. Then, Select their recommended dimensions, as shown in items 22 \& 24, respectively. Also, Draw a schematic layout for this underground water tank, according to NFPA 20 \& 22 requirements. (4 Marks)

21. For Fire water storage Tanks for One Hour ( 60 mins), the storage tank volume will be

(a) $288 \mathrm{~m}^{3}$

(b) $360 \mathrm{~m}^{3}$

(c) $432 \mathrm{~m}^{3}$

(d) $576 \mathrm{~m}^{3}$

22.For Fire water storage Tanks for One Hour ( 60 mins), the storage tank recommended dimensions ( $\mathrm{L} \times \mathrm{W} \times \mathrm{H})$ will be _.

\begin{tabular}{|c|c|c|}
\hline $\begin{array}{l}\text { (a) } L=10 \mathrm{~m}, W=9 \mathrm{~m}, \mathrm{H}=4 \mathrm{~m} \\
\text { (b) } L=9 \mathrm{~m}, W=8 \mathrm{~m}, \mathrm{H}=4 \mathrm{~m} \\
\text { (c) } L=12 \mathrm{~m}, W=7.5 \mathrm{~m}, \mathrm{H}=4 \mathrm{~m} \\
\text { (d) } L=12 \mathrm{~m}, W=10 \mathrm{~m}, \mathrm{H}=4.8 \mathrm{~m}\end{array}$ & Explanation (1 mark) & diagram \\
\hline
\end{tabular}

23. For Fire water storage Tanks for One Hour \& half ( 90 mins), the storage tank volume will be

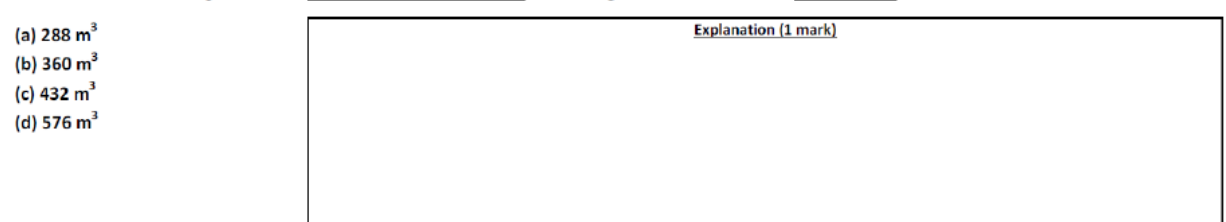

24. For Fire water storage Tanks for One Hour \& half ( 90 mins), the storage tank recommended dimensions (LxWxH) will be__.

\begin{tabular}{l|l|l} 
(a) $\mathrm{L}=10 \mathrm{~m}, \mathrm{~W}=9 \mathrm{~m}, \mathrm{H}=4 \mathrm{~m}$ & Explanation (1 mark) & diagram
\end{tabular}

(b) $L=9 \mathrm{~m}, W=6 \mathrm{~m}, \mathrm{H}=8 \mathrm{~m}$

(c) $L=12 \mathrm{~m}, W=7.5 \mathrm{~m}, \mathrm{H}=4 \mathrm{~m}$

(d) $L=12 \mathrm{~m}, W=9 \mathrm{~m}, \mathrm{H}=4 \mathrm{~m}$

\begin{tabular}{|l|l|}
\hline Explanation (1 mark) & \\
& \\
& \\
& \\
\hline
\end{tabular}

Final Exam - Industrial Safety - January 2019 (2nd year Mechanical Students)

(b) 
Question 3. Health, Safety and Environment of Mega Projects in Egypt (Hot Spot Questions)

(12 Marks)

Recently, many projects have been started in Egypt. About 34 of multidisciplinary groups have been joined to investigate all of these currently Mega projects, as HSE case study. In the present work, more than 34 technical reports have been prepared to gain deep understanding in different HSE Applications, to cover many Industries and Construction Activities. Most of these reports were prepared carefully by second year students, during this current semester. The set of these performed case studies have been listed in the following symmetrical matrix, with the areas where the case studies were considered, as can be seen in Table 3.1.

Table 3.1: Symmetrical Matrix for the case studies performed during current semester 2018/2019, to be used for Questions $(3.1,3.2, \& 3.3)$.

\begin{tabular}{|c|c|c|c|c|c|c|c|c|c|}
\hline \multicolumn{2}{|r|}{$\begin{array}{l}\text { Selective } \\
\text { S Groups }\end{array}$} & \multirow{2}{*}{ 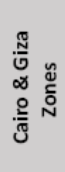 } & \multirow{2}{*}{ 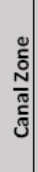 } & \multirow{2}{*}{ 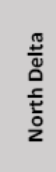 } & \multirow{2}{*}{ 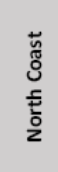 } & \multirow{2}{*}{ 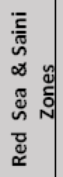 } & \multirow{2}{*}{ 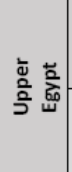 } & \multicolumn{2}{|l|}{$\begin{array}{l}\text { Selective } \\
\text { T Groups }\end{array}$} \\
\hline Code & Project Title & & & & & & & Project Title & Code \\
\hline S-201 & New Alameen City & & & & s & & $\mathrm{T}$ & Asyut Bridges & T-201 \\
\hline S-202 & Le Grand Egyptian Museum & $S, T$ & & & & & & Cairo Metro Line 3-Airport Area & T-202 \\
\hline S-203 & El-Galala Mountain City & $\mathrm{T}$ & s & $\mathrm{T}$ & & & $\mathrm{T}$ & Banking Systems & T-203 \\
\hline S-204 & ASU Educational Hospitals & $\mathrm{s}$ & & $\mathrm{T}$ & & & & BU Educational Hospitals & T-204 \\
\hline S-205 & Cement Factory in Beni Suef & $\mathrm{T}$ & & & & & $\mathrm{S}, \mathrm{T}$ & Water Treatment Plants & T-205 \\
\hline S-206 & BU Specialized Hospital & $\mathrm{T}$ & & $s$ & & & & Ministries Movement to New Capital & T-206 \\
\hline S-207 & Maspero Triangle Area & $S, T$ & & & $\mathrm{~T}$ & & & Large \& Mega Stores in New Cities & T-207 \\
\hline S-208 & Dates Manufacturing & $\mathrm{S}, \mathrm{T}$ & & 5 & & $s$ & $\mathrm{~s}$ & Design for Rod El-Farg Axis & $\mathrm{T}-208$ \\
\hline S-209 & El-Gouna City & & & $\mathrm{T}$ & & $s$ & & Meat Production & T-209 \\
\hline S-210 & BU Fire Fighting System & $\mathrm{T}$ & & $\mathrm{S}, \mathrm{T}$ & & & & Garbage Collection \& Recycling & $\mathrm{T}-210$ \\
\hline S-211 & Al-Azhar AL-Sharif Library & $\mathrm{s}$ & & & & $\mathrm{T}$ & & Industrial Safety Factory & $\mathrm{T}-211$ \\
\hline S-212 & Construction for Rod El-Farg Axis & $\mathrm{S}, \mathrm{T}$ & & $\mathrm{S}, \mathrm{T}$ & $S, T$ & & & OHTLs \& Fiber optics Cables & $\mathrm{T}-212$ \\
\hline S-213 & LNG industry \& Transportation & $\mathrm{s}$ & & & & & & Medicine Factories & $\mathrm{T}-213$ \\
\hline S-214 & Alexandria 2032 Olympic City & & & $S, T$ & & & & Alexandria Pivoted Tram Lines & $\mathrm{T}-214$ \\
\hline S-215 & Multi-Media City & S, T & & & & & & New Capital Power Station & $\mathrm{T}-215$ \\
\hline S-216 & Electronic Learning \& Testing & $\mathrm{s}$ & s & $\mathrm{s}$ & $s$ & s & s & & \\
\hline S-217 & Electronic Devices Factories & & & $\mathrm{s}$ & & & $\mathrm{s}$ & & \\
\hline S-218 & Wind Farms, Water Desalination & & & & & s & & & \\
\hline S-219 & Server \& Data Centers & $\mathrm{s}$ & & & & & & & \\
\hline
\end{tabular}

Question 3.1 Hot Spot Question (3 marks)

$\underline{\text { Select }}$ at least Six of these listed of these Mega projects, and $\underline{\text { Indicate }}$ them on the attached Map for Egypt, as can be seen in Figure 3.1.

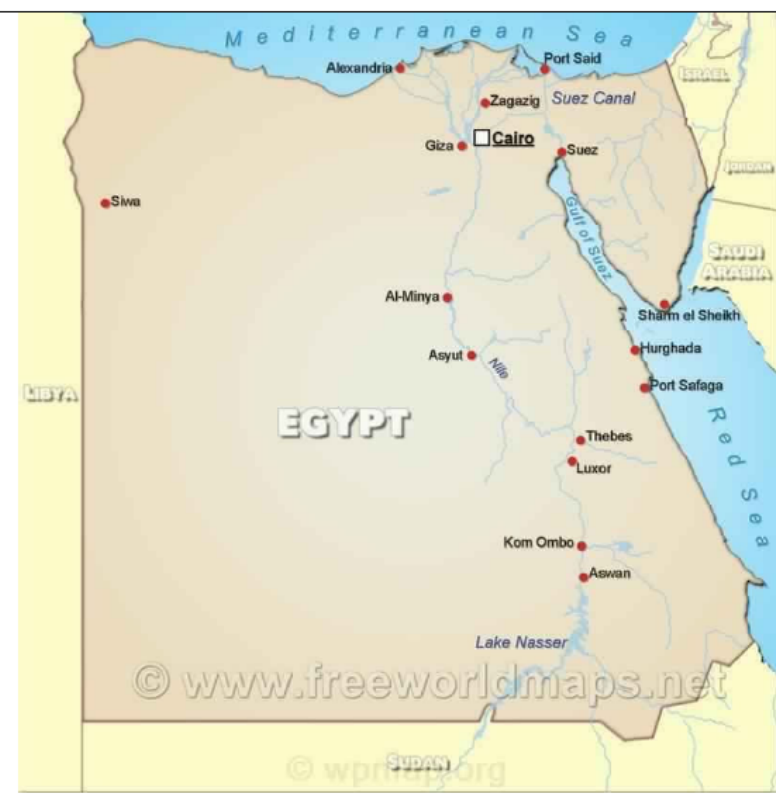

Figure 3.1 : Egypt Map for Hot spot question (Question 3.1).

Final Exam - Industrial Safety - January 2019 (2" year Mechanical Students) 


\section{Health, Safety and Environment of Meqa Projects in Eqypt (Hot Spot Question) (12 Marks)}

Recently, many projects have been started in Egypt. About 34 of multidisciplinary groups have been joined to investigate all of these currently Mega projects, as HSE case study. In the present work, more than 34 technical reports have been prepared to gain deep understanding in different HSE Applications, to cover many Industries and Construction Activities. Most of these reports were prepared carefully by second year students, during this current semester. The set of these performed case studies have been listed in the following symmetrical matrix, with the areas where the case studies were considered, as can be seen in Table 3.1.

Table 3.1: Symmetrical Matrix for the case studies performed during current semester 2018/2019,

to be used for Questions $(3.1,3.2, \& 3.3)$.

\begin{tabular}{|c|c|c|c|c|c|c|c|c|c|}
\hline \multicolumn{2}{|r|}{$\begin{array}{l}\text { Selective } \\
\text { S Groups }\end{array}$} & \multirow{2}{*}{ 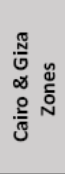 } & \multirow{2}{*}{ 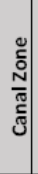 } & \multirow{2}{*}{ 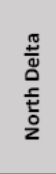 } & \multirow{2}{*}{ 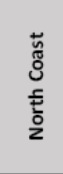 } & \multirow{2}{*}{ 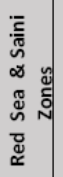 } & \multirow{2}{*}{ ڤั } & \multicolumn{2}{|l|}{$\begin{array}{l}\text { Selective } \\
\text { T Groups }\end{array}$} \\
\hline Code & Project Title & & & & & & & Project Title & Code \\
\hline S-201 & New Alameen City & & & & $s$ & & $\mathrm{~T}$ & Asyut Bridges & $\mathrm{T}-201$ \\
\hline S-202 & Le Grand Egyptian Museum & $\mathrm{S}, \mathrm{T}$ & & & & & & Cairo Metro Line 3-Airport Area & $\mathrm{T}-202$ \\
\hline S-203 & El-Galala Mountain City & $\mathrm{T}$ & $s$ & $T$ & & & $T$ & Banking Systems & T-203 \\
\hline S-204 & ASU Educational Hospitals & $\mathrm{s}$ & & $T$ & & & & BU Educational Hospitals & $\mathrm{T}-204$ \\
\hline S-205 & Cement Factory in Beni Suef & $\mathrm{T}$ & & & & & $\mathrm{S}, \mathrm{T}$ & Water Treatment Plants & T-205 \\
\hline S-206 & BU Specialized Hospital & $\mathrm{T}$ & & $\mathrm{s}$ & & & & Ministries Movement to New Capital & T-206 \\
\hline S-207 & Maspero Triangle Area & $\mathrm{S}, \mathrm{T}$ & & & $\mathrm{T}$ & & & Large \& Mega Stores in New Cities & $\mathrm{T}-207$ \\
\hline S-208 & Dates Manufacturing & $\mathrm{S}, \mathrm{T}$ & & $s$ & & $\mathrm{~s}$ & 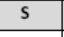 & Design for Rod El-Farg Axis & T-208 \\
\hline S-209 & El-Gouna City & & & $\mathrm{T}$ & & $\mathrm{s}$ & & Meat Production & T-209 \\
\hline S-210 & BU Fire Fighting System & $T$ & & S, T & & & & Garbage Collection \& Recycling & $\mathrm{T}-210$ \\
\hline S-211 & Al-Azhar AL-Sharif Library & $\mathrm{s}$ & & & & $\mathrm{T}$ & & Industrial Safety Factory & $\mathrm{T}-211$ \\
\hline S-212 & Construction for Rod El-Farg Axis & $\mathrm{S}, \mathrm{T}$ & & $S, T$ & S,T & & & OHTLs \& Fiber optics Cables & $\mathrm{T}-212$ \\
\hline S-213 & LNG industry \& Transportation & $\mathrm{s}$ & & & & & & Medicine Factories & $\mathrm{T}-213$ \\
\hline S-214 & Alexandria 2032 Olympic City & & & $\mathrm{S}, \mathrm{T}$ & & & & Alexandria Pivoted Tram Lines & $\mathrm{T}-214$ \\
\hline S-215 & Multi-Media City & $S, T$ & & & & & & New Capital Power Station & $\mathrm{T}-215$ \\
\hline S-216 & Electronic Learning \& Testing & $\mathrm{s}$ & s & $\mathrm{s}$ & $s$ & s & $s$ & & \\
\hline S-217 & Electronic Devices Factories & & & $\mathrm{s}$ & & & s & & \\
\hline S-218 & Wind Farms, Water Desalination & & & & & $\mathrm{s}$ & & & \\
\hline S-219 & Server \& Data Centers & s & & & & & & & \\
\hline
\end{tabular}

Question 3.1 Hot Spot Question (3 marks)

$\underline{\text { Select }}$ at least $\underline{\text { Six }}$ of these listed of these Mega projects, and Indicate them on the attached Map for Egypt, as can be seen in Figure 3.1.

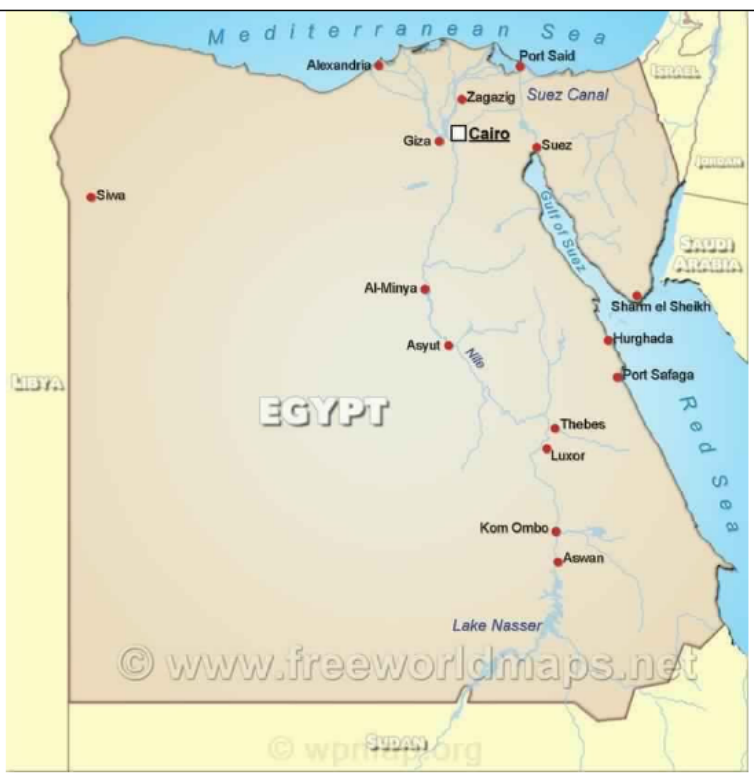

Figure 3.1 : Egypt Map for Hot spot question (Question 3.1).

Final Exam - Industrial Safety - January 2019 (2"nd year Mechanical Students)

(c) 
Benha University

Benha Faculty of Engineering

Mechanical Engineering Department

First Term of Academic Year 2020/2021

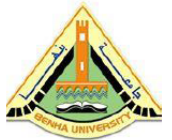

Industrial Safety (HSE)

(M-1283)

$2^{\text {rd }}$ year Electrical Dept. Students

Time: 2 hours

\section{Question 2 True/False and Matching Questions (Page 3) on Chapters 1 \& 2 and Chapters 9-16}

\section{Question 2.1 True/False Questions (2 marks)}

\section{(6 marks)}

25. Decibel (db) is a unit used to measure Lighting Intensity in Tunnels Entrances and Exits.
(a) True

(b) False

26. Tripping hazards, Slipping hazard, and Falling from a height are classified as Movement of people Hazards.

(a) True

(b) False

27. UK HSE guidance for normal lifting gives identical weights can be carried by both Men and Women, as per SDG \#5.
(a) True

(b) False

28. Cooking Oil Fires are classified as Class F Fires.
(a) True
(b) False

Question 2.2 Matching Question (2 marks)

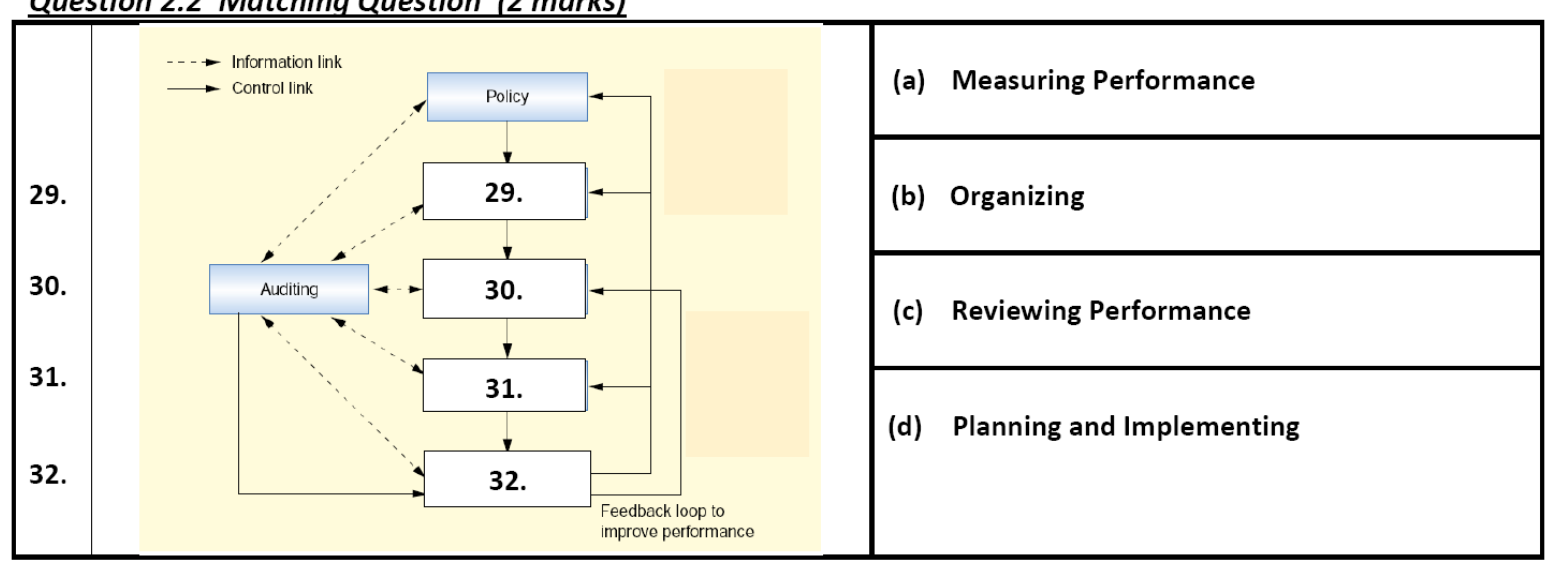

Question 2.3 Matching Question (2 marks)

33. Eyewash Station in Chemical Factories

34. Do not use Elevators in Fire Case

35. Wear Face Mask

36. Unauthorized persons not to use this machine

\begin{tabular}{|l|l|}
\hline (a) & (b) \\
\hline (c) & (d) \\
\hline
\end{tabular}

Final Exam - Industrial Safety - January $2021 \quad\left(2^{\text {nd }}\right.$ year Electrical Students) 
Question 3. Health, Safety and Environment of Projects in Egypt (Hot Spot \& Short Essay Questions) (12 Marks)

Recently, many projects have been started in Egypt. About 25 of multidisciplinary groups (MEP groups) have been joined to investigate all of these currently Mega projects, as HSE case study. In the present work, more than 25 technical reports have been prepared to gain deep understanding in different HSE Applications, to cover many Industries and Construction Activities. Most of these reports were prepared carefully by second year students, during this current semester. The set of these performed case studies have been listed in the following symmetrical matrix, with the areas where the case studies were considered, as can be seen in Table 3.1.

Table 3.1: Symmetrical Matrix for the case studies performed during current semester 2020/2021,

\begin{tabular}{|c|c|c|c|c|c|c|c|c|c|}
\hline \multicolumn{2}{|r|}{$\begin{array}{l}\text { MEP Groups } \\
\text { ST-401 to ST-413 }\end{array}$} & \multirow{2}{*}{ 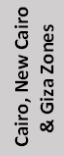 } & \multirow{2}{*}{ 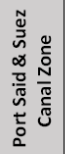 } & \multirow{2}{*}{ 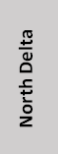 } & \multirow{2}{*}{ 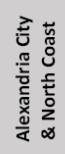 } & \multirow{2}{*}{ 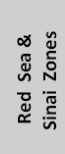 } & \multirow{2}{*}{ 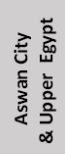 } & \multicolumn{2}{|l|}{$\begin{array}{l}\text { MEP Groups } \\
\text { ST-414 to ST-425 }\end{array}$} \\
\hline Code & Project Title & & & & & & & Project Title & Code \\
\hline ST-401 & Nasr City Development & $\begin{array}{l}\text { ST-401 } \\
\text { ST-414 }\end{array}$ & & & & & & Art \& Culture City in NCAP & ST-414 \\
\hline ST-402 & Solar Driven Hospitals & \multicolumn{5}{|c|}{ ST-415 } & $\begin{array}{l}\text { ST-402 } \\
\text { ST-415 }\end{array}$ & Education \& Sports Activities & ST- 415 \\
\hline ST-403 & Field Isolation Hospitals & $\begin{array}{l}\text { ST-403 } \\
\text { ST-416 }\end{array}$ & \multicolumn{5}{|c|}{ ST-416 } & Educational \& Isolation Hospitals & ST-416 \\
\hline ST-404 & Four Seasons Hotels \& Resorts & $\begin{array}{l}\text { ST-404 } \\
\text { ST-417 }\end{array}$ & \multicolumn{5}{|c|}{ ST-417 } & Hybrid Educational in New Universities & ST-417 \\
\hline ST-405 & Robotics \& Automation in Hospitals & & & ST-405 & ST-418 & & & Waste Management \& Recycle & ST-418 \\
\hline ST-406 & Cairo Metro Line 3 - East Cairo Zone & $\begin{array}{l}\text { ST-406 } \\
\text { ST-419 }\end{array}$ & \multicolumn{5}{|c|}{ ST-419 } & Hybrid Educational Systems & ST-419 \\
\hline ST-407 & High Rise Buildings in NCAP & $\begin{array}{l}\text { ST-407 } \\
\text { ST-420 }\end{array}$ & & & & & & 500500 Cancer Hospital & ST-420 \\
\hline ST-408 & New Alameen City \& University & \multicolumn{3}{|c|}{ ST-421 } & $\begin{array}{l}\text { ST-408 } \\
\text { ST-421 }\end{array}$ & \multicolumn{2}{|c|}{ ST-421 } & Precautionary Measures in Praying Areas & ST-421 \\
\hline ST-409 & Qaluib City Development \& Metro II & & & ST-409 & ST-422 & & & Steel Factories and Industries & ST-422 \\
\hline ST-410 & Vaccine Transportation \& Storage & \multicolumn{6}{|c|}{$\begin{array}{l}\text { ST-410, } \\
\text { ST-423 }\end{array}$} & IT \& COVID-19 Relationship & ST-423 \\
\hline ST-411 & Olympic City in NCAP & $\begin{array}{l}\text { ST-411 } \\
\text { ST-424 }\end{array}$ & & & ST-424 & ST-424 & & Express Electrical Train \& Iconic Tower & ST-424 \\
\hline ST-412 & Newborn Hospitals \& Incubators & ST-425 & & ST-412 & & & & IT \& COVID-19 Relationship & ST-425 \\
\hline ST-413 & Juices \& Soft Drink Industries & & & ST-413 & & & & \multicolumn{2}{|c|}{ ST: studied by Sunday's \&Tuesday's MEP groups } \\
\hline
\end{tabular}

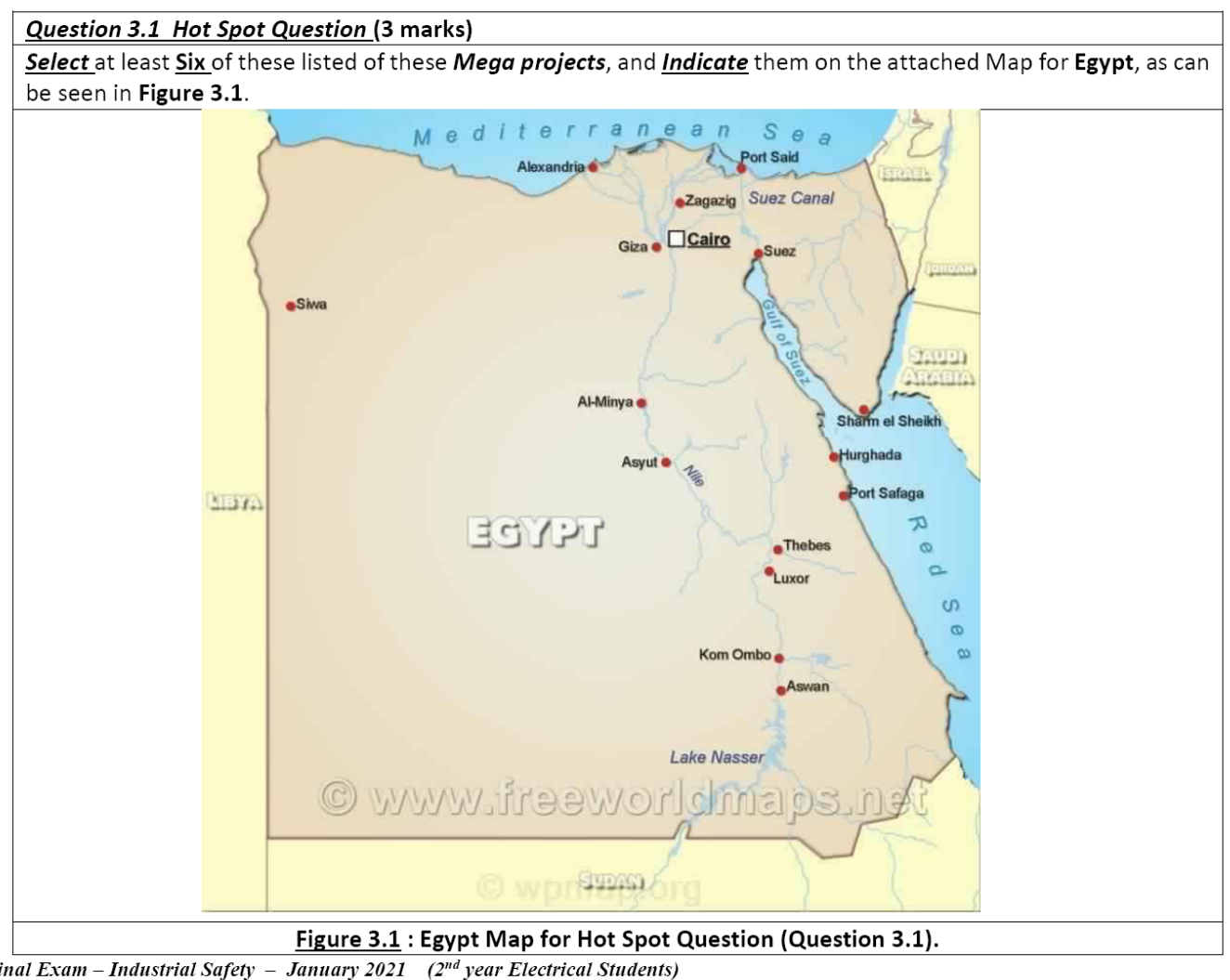

Final Exam - Industrial Safety - January 2021 (2 $2^{\text {nd }}$ year Electrical Students)

Page 4 | 7

(d)

Figure 2. Development for summative assessments, from the Fall 2017 to the Spring 2021. (a) open response questions for 2017/2018, (b) multi response question for 2018/2019 \& 2019/2020, (c) hot spot question for 2018/2019 \& 2019/2020 and (d) 2020/2021 multi response questions and hot spot question. 


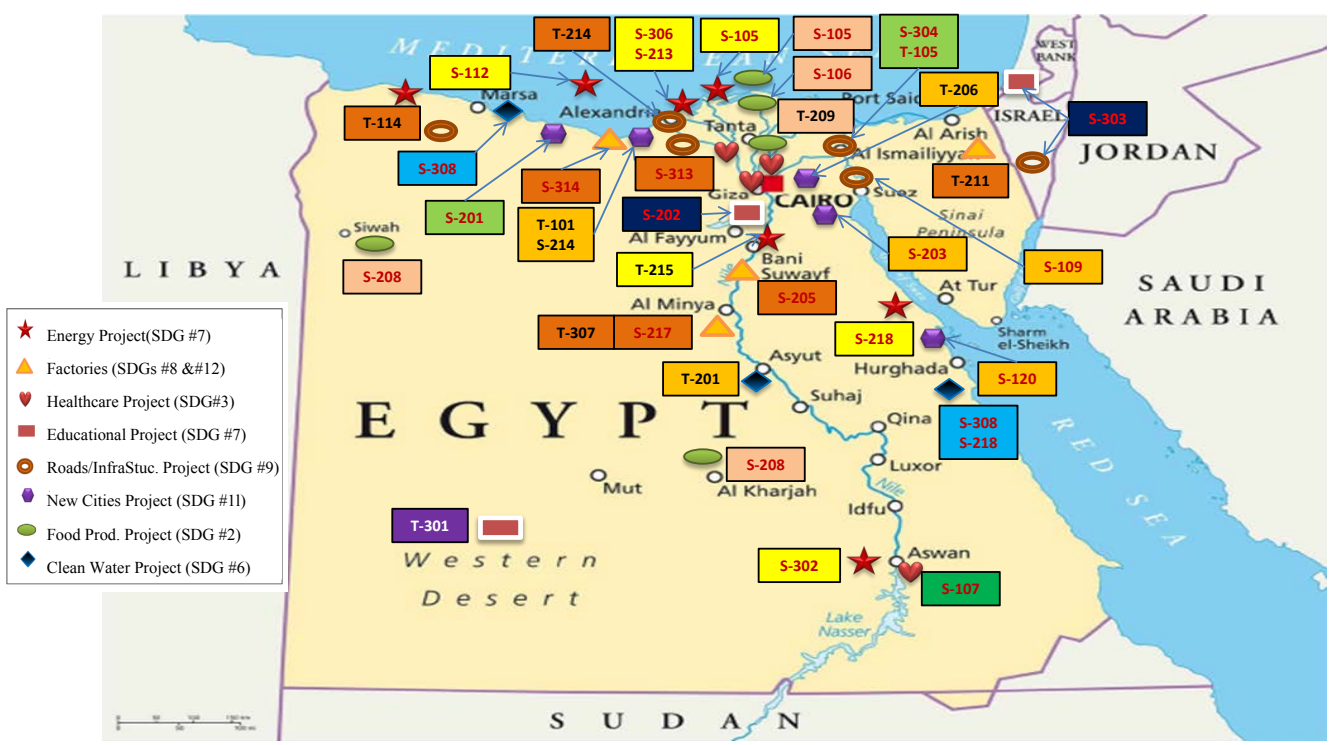

(a)

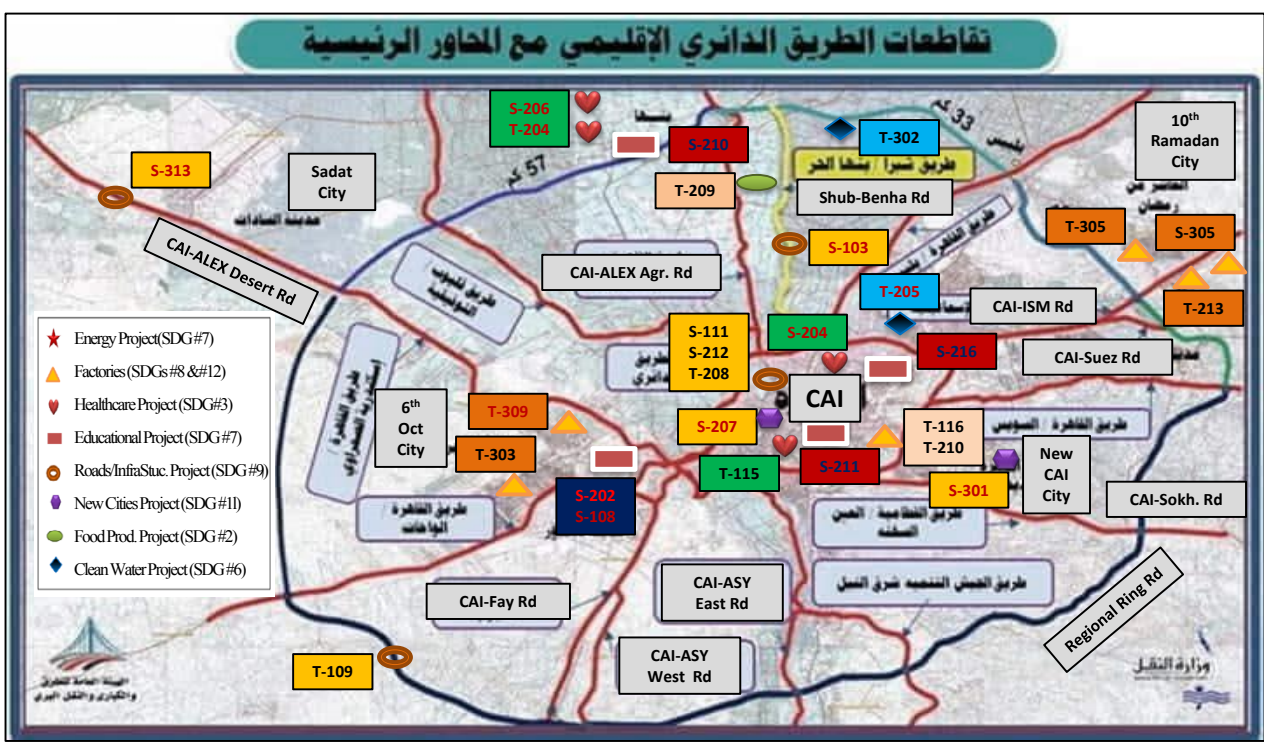

(b)

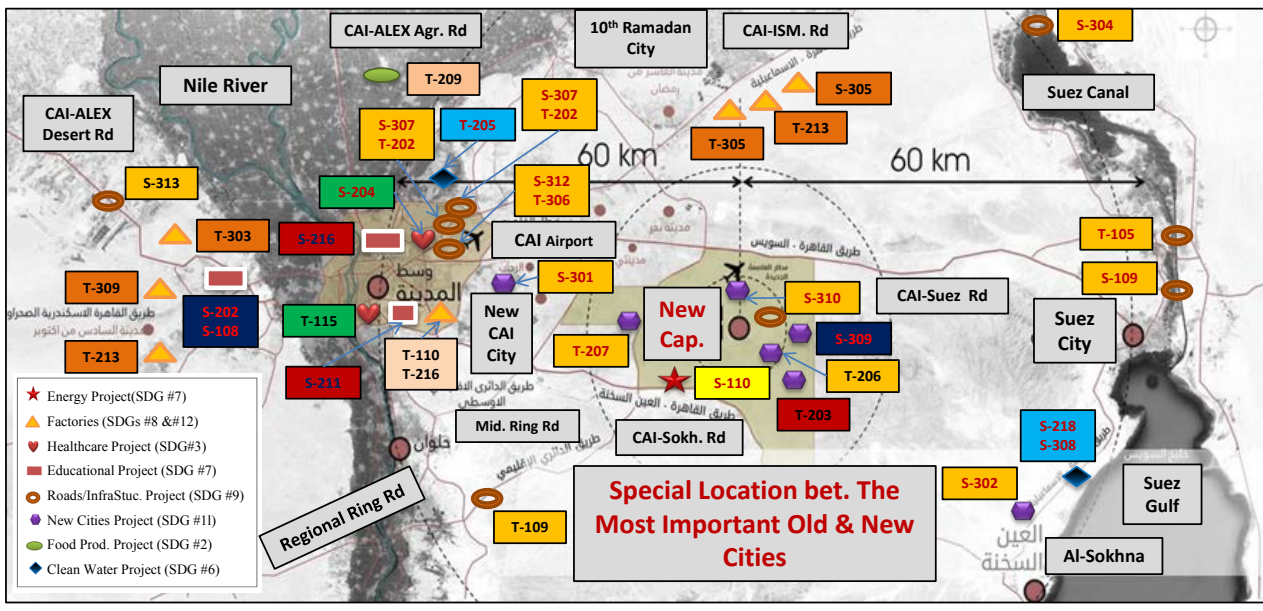

(c) 


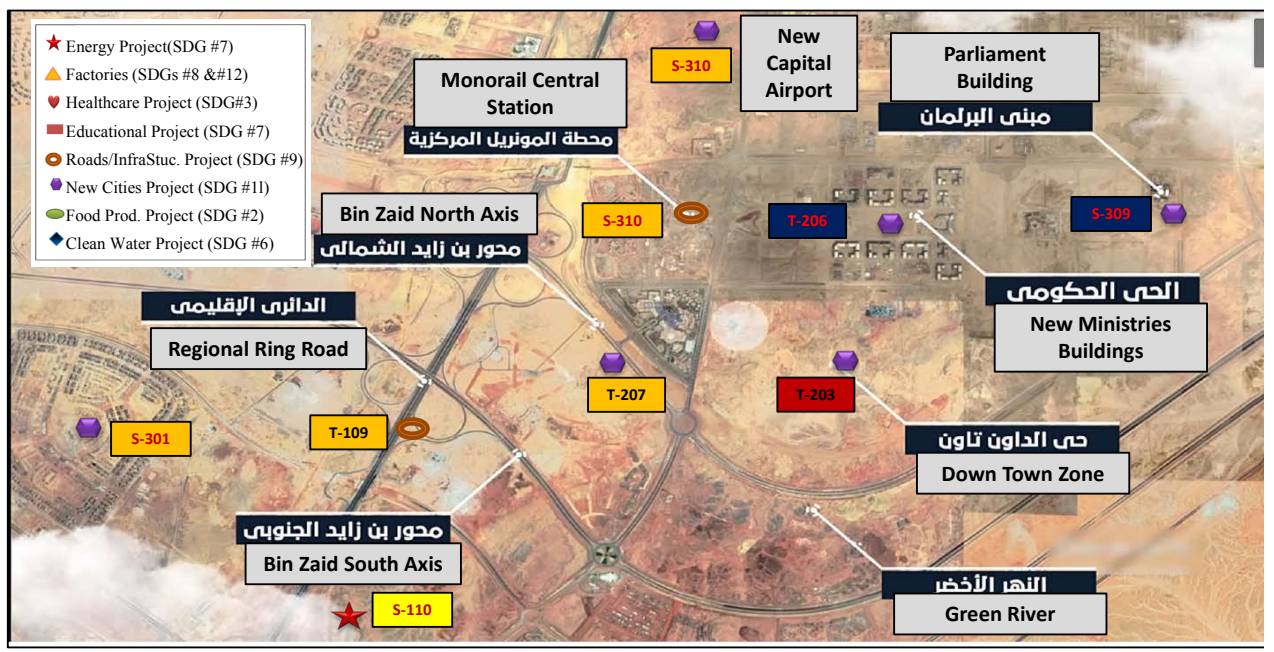

(d)

Figure 3. Distribution of MDRPs on Egypt full and enlarged maps. (a) Egypt full map, (b) Cairo regional ring road map, (c) east Cairo, new Capital and Suze canal zones and (d) new Capital plot plan.

surrounds Cairo zone and its intersections with Cairo's main corridors. However, both Figure 3(c) and Figure 3(d) illustrate the distribution of selective MDRPs on enlarged maps for Cairo, new Cairo, and new Capital. The data reduction is used to present a selective number of these MDRPs in this article as results of Egypt mission 2030. Figure 4 depicts distribution of all MDRPs on the same zones of Egypt listed above. Figure 4(a) depicts the number of MDRPs (NMDRP) studied on each of these listed zones of Egypt, using histogram. However, Figure 4(b) displays the percentage of MDRPs focused on each of these listed zones of Egypt, using pie chart.

\subsection{Classification of MDRPs on SDGs}

The classification of performed MDRPs on SDGs for both before and after the COVID-19 are presented in Figure 5 using both histogram (Figure 5(a)), and pie charts before the COVID-19 (Figure 5(b)), and after the COVID-19 (Figure 5(c)). Figure 5(a) demonstrates distribution of MDRPs on the SDGs studied before and after the COVID-19 using histogram. The relationships between the COVID-19 pandemic and both healthcare facilities and advanced educational systems are pronounced due to the impacts of the COVID-19 on the selected occupational health and safety curriculum. Figure 5(a) displays that MDRPs are distributed on many intended SDGs such as $3,4,6,7,9,11,12,13$ and 16 to facilitate gain a deep understanding for most SDGs and targets. Figure 5(b) and Figure 5(c) indicate a comparative study between MDRPs before and after the COVID-19 to demonstrate the COVID-19 impact on the cross-sectional studies. Figure 5(b) presents the percentage of MDRPs focused on SDGs before COVID-19 from 2017-2019, however Figure 5(c) presents the percentage of MDRPs focused on SDGs after COVID-19 from 2017-2020. The comparison 


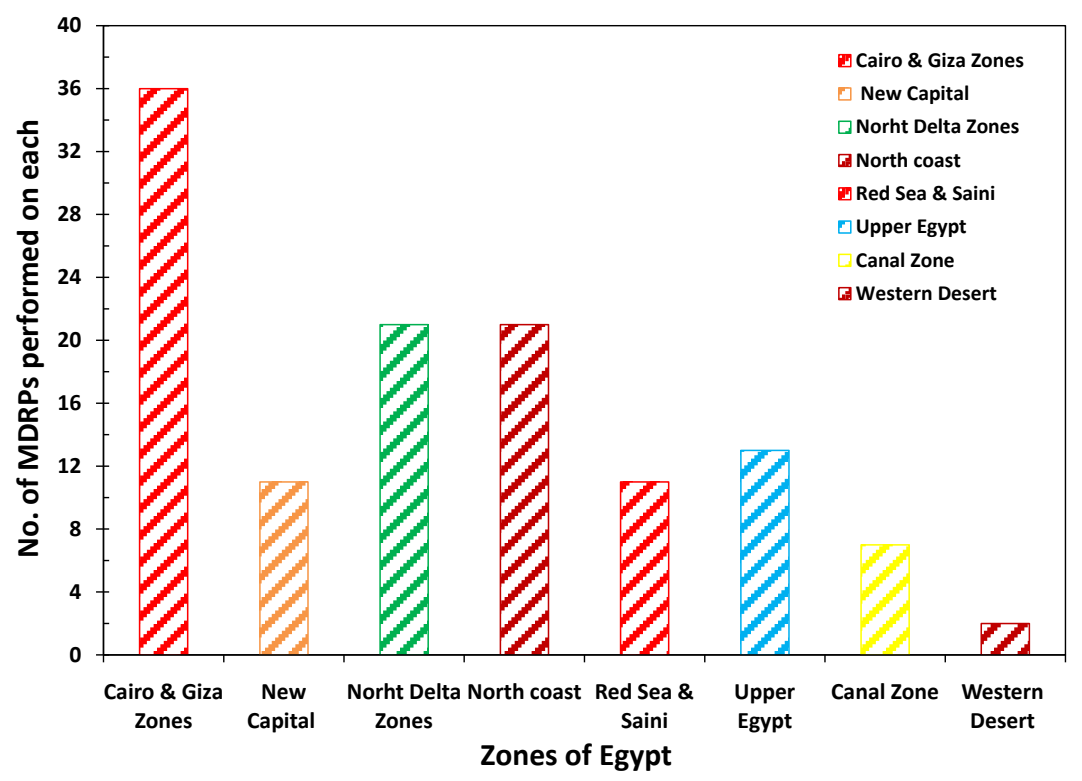

(a)
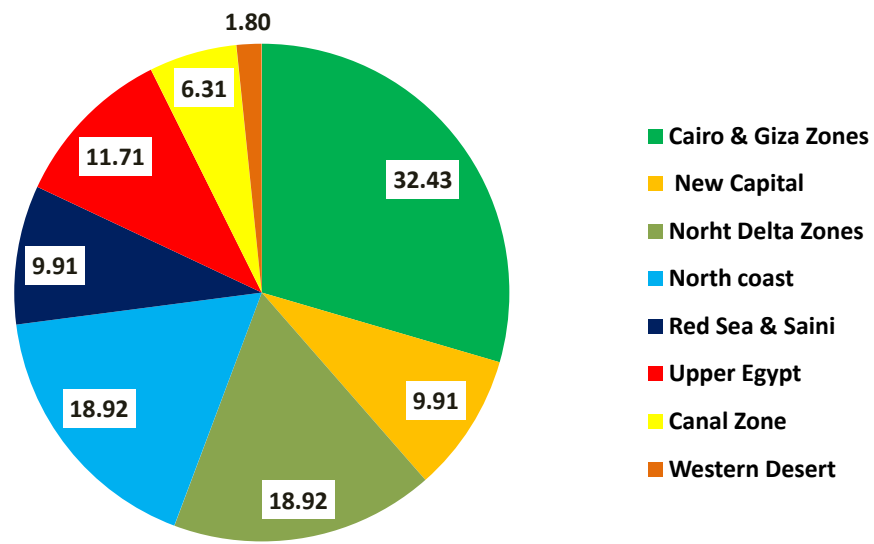

(b)

Figure 4. Distribution of MDRPs (NMDRP) on Egypt zones (a) using histogram and (b) using pie chart.

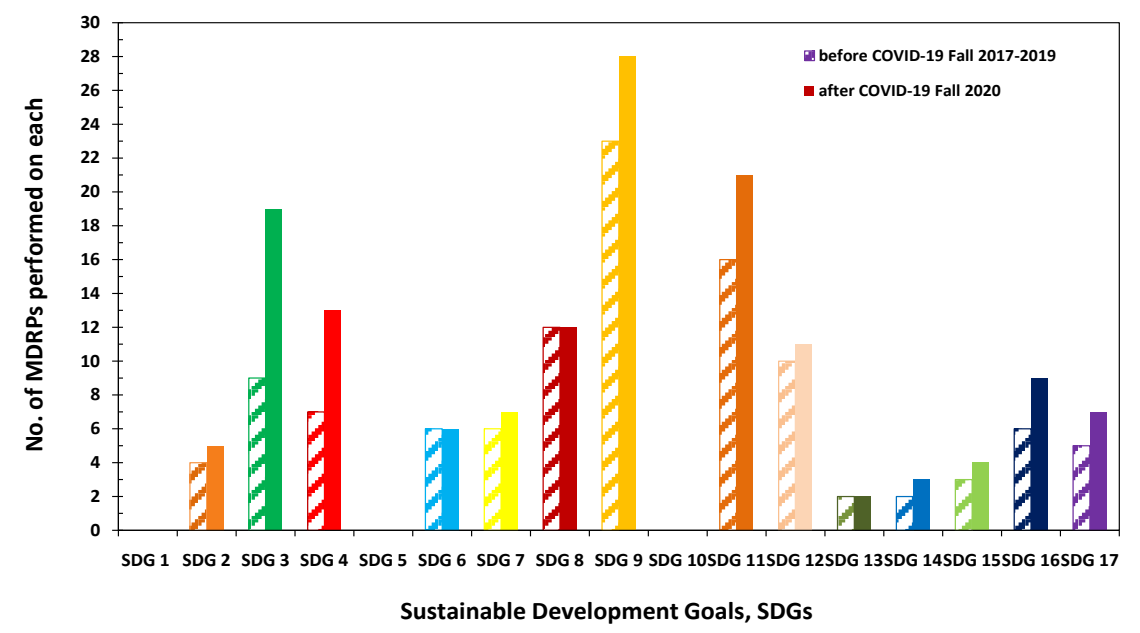

(a) 


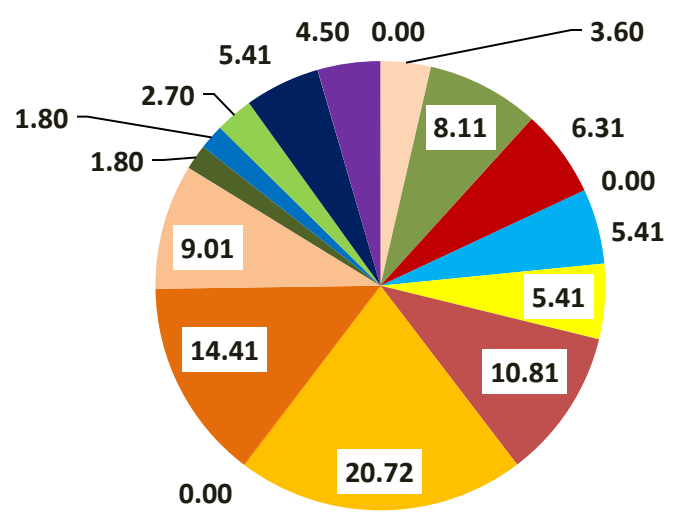

SDG 1

SDG 2

SDG 3

SDG 4

SDG 5

SDG 6

SDG 7

SDG 8

SDG 9

SDG 10

SDG 11

SDG 12

SDG 13

SDG 14

SDG 15

-SDG 16

(b)

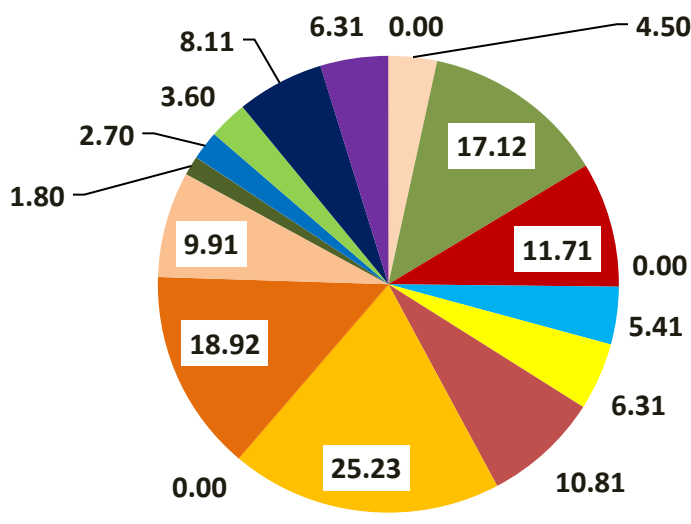

SDG 1

SDG 2

SDG 3

$\square$ SDG 4

SDG 5

SDG 6

SDG 7

SDG 8

SDG 9

SDG 10

SDG 11

SDG 12

SDG 13

SDG 14

SDG 15

- SDG 16

(c)

Figure 5. Distribution of current MDRPs (NMDRP) before and after COVID-19 for SDGs from SDG 1 to SDG 17. (a) Histogram comparison, (b) Pie chart before COVID-19 and (c) Pie chart after COVID-19.

between these recorded percentages from both Figure 5(b) and Figure 5(c) highlights on the increasing percentage on highly affected SDGs 3, 4, 9, and 11. On the other hand, fixed percentages are recorded for unaffected SDGs 6, and 7. The recorded increasing are highly observed for SDG 3 from $8.11 \%$ to $17.12 \%$, SDG 4 from $6.31 \%$ to $11.7 \%$, SDG 9 from $20.72 \%$ to $25.23 \%$, and SDG 11 from $14.41 \%$ to $18.92 \%$. On the other side, some recorded fixed percentages recorded for SDG 6 at $5.41 \%$, for SDG 7 at $10.81 \%$ and for 12 at $1.8 \%$.

\section{Discussion}

\subsection{Comparison between MDRPs on SDGs 2, 3, 4 and Their Targets}

Figure 6(a) depicts selective MDRPs focused on SDG 2 such as food industry and food engineering, Gulyion fish farming in Kafr El-Sheikh zone, meat production enhancement in north Delta zone and at BU Faculty of Agriculture in Mushtoher zone, food storage silos on coastal ports in Dumyat and Alexandria cities, and megastores in malls of new Cairo city. The results of MDRPs performed on SDG 2 are in consistent with the SDG 2 targets numbered from 2.1 to 
2.5, 2.A, and 2.B (Table 2 and Figure 6(a)). As shown in Figure 5(a) that several MDRPs focused on SDG 2 are in complying with targets 2.1 to 2.5, 2.A, and 2.B, listed in Table 2. Meanwhile, Figure 6(b) illustrates selective MDRPs focused on SDG 3 for healthcare facilities, medical informatics, and public health, located in different zones in Egypt, such as 57,357 hospital, 500,500 cancer hospital,
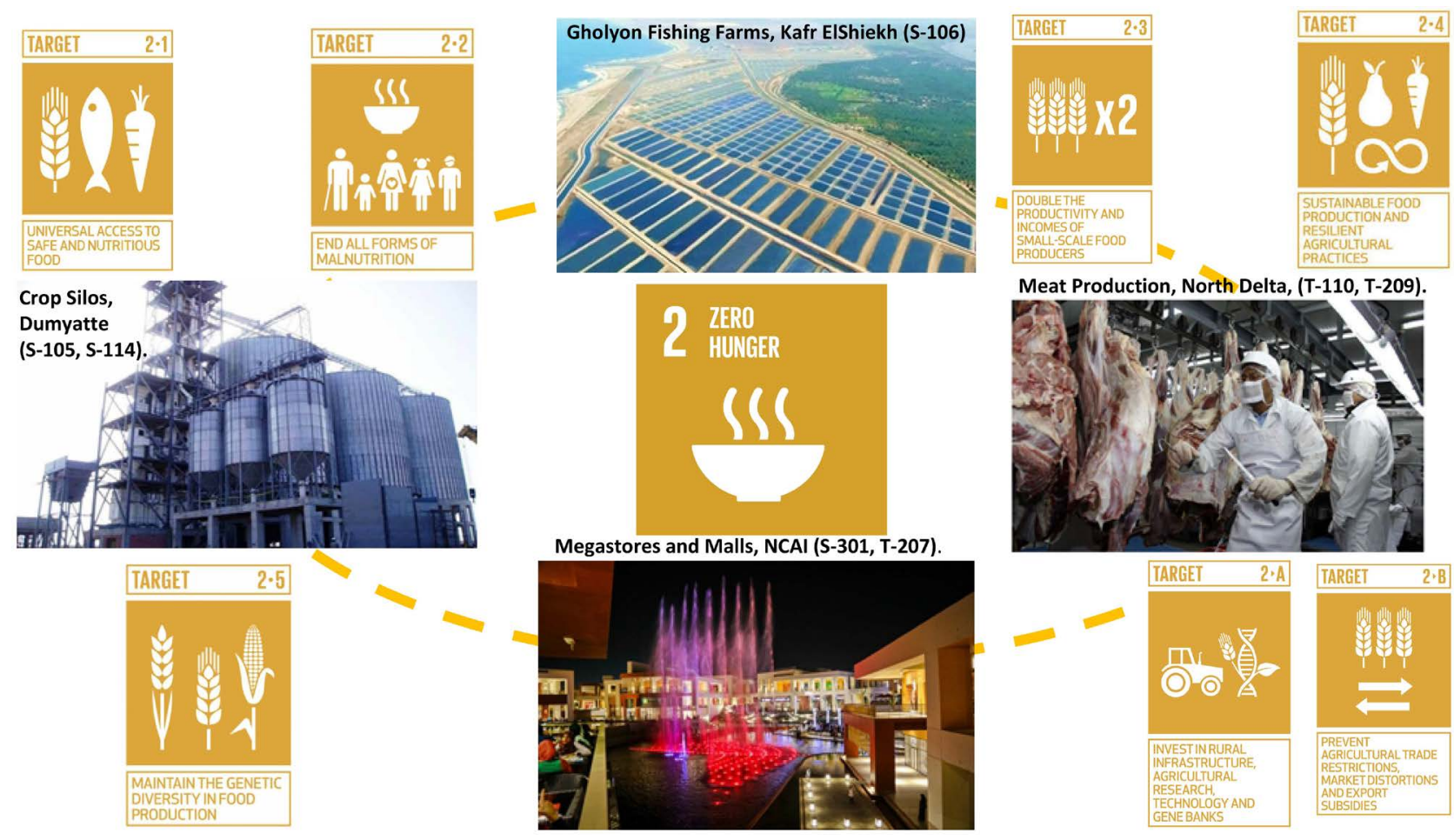

(a)
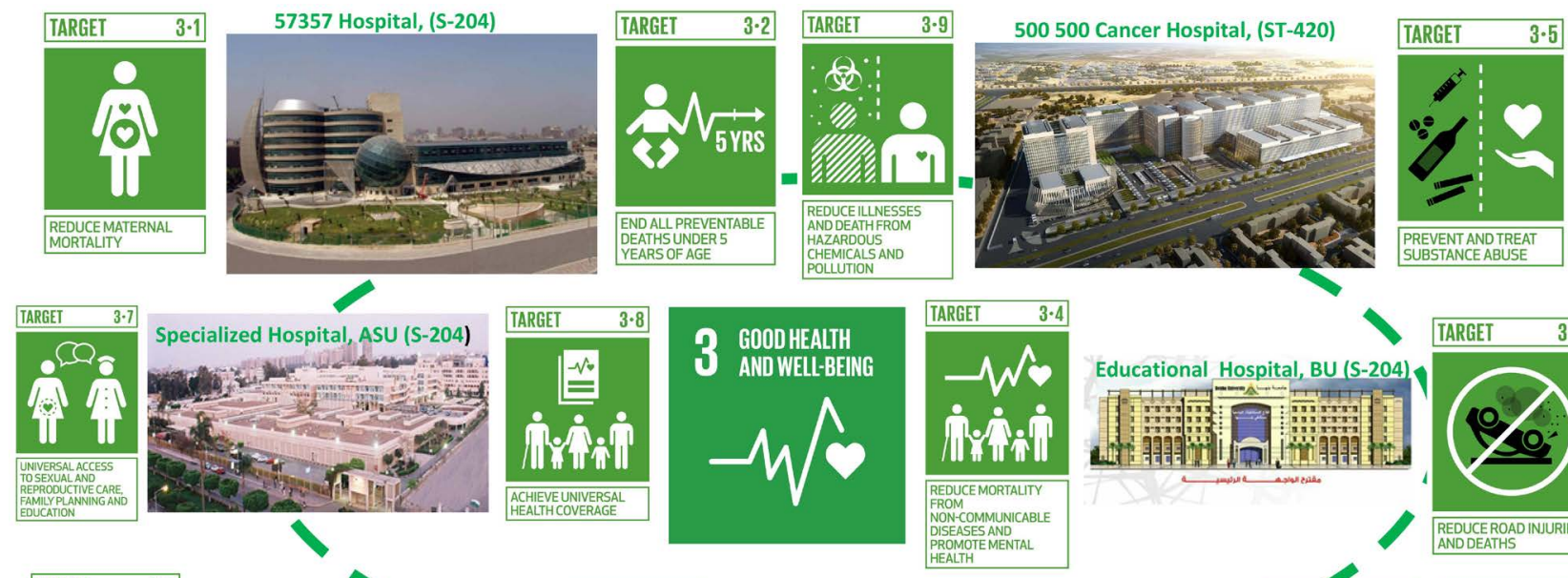

\begin{tabular}{|l|}
\hline TARGET $\quad 3 \cdot 6$ \\
\hline
\end{tabular}
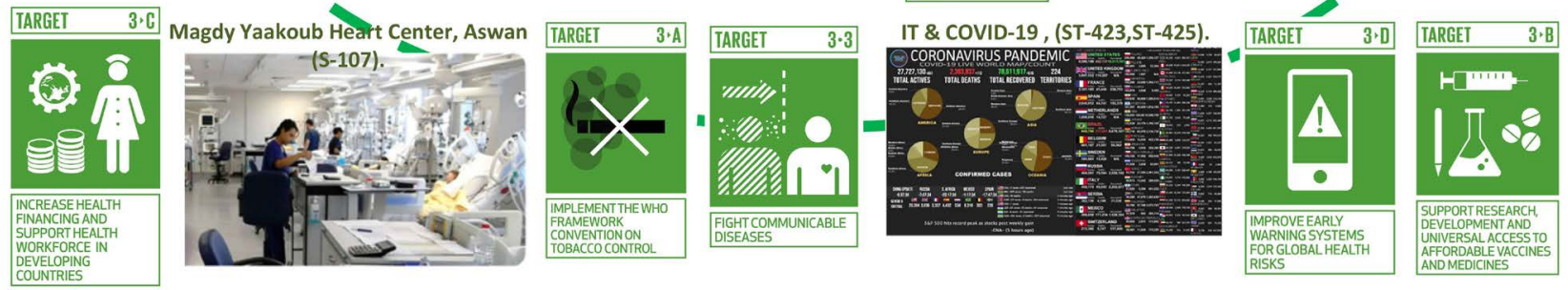

(b) 


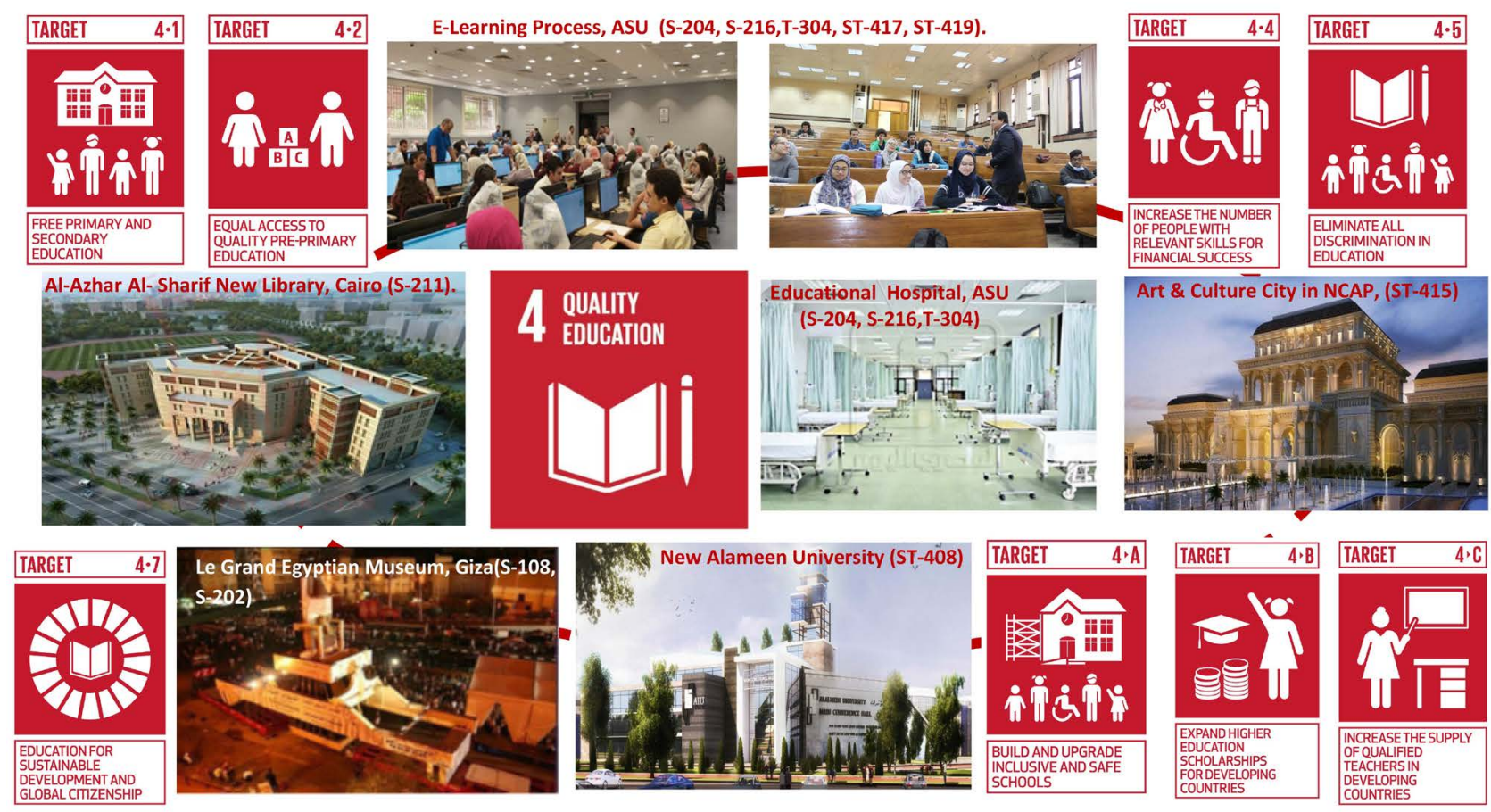

(c)

Figure 6. SDGs 2, 3, and 4 targets and performed MDRPs. (a) SDG 2 and MDRPs on SDG 2, (b) SDG 3 and MDRPs on SDG 3 and (c) SDG 4 and MDRPs on SDG4.

ASU specialized hospital, development of BU educational hospital, BU specialized hospital, and heart center in Aswan city. One group of students conducted their MDRP on eye hazards, and eye surgical processes in Egyptian hospitals for eye surgeries. Another group conducted their MDRP on the diseases for human beings, such as dentistry, mental, epilepsy. More recently some groups conducted their MDRPs on the COVID-19, medical informatics and relationship with information technology to apply precautionary measures in most human activities. Most of those students monitored and studied the hazards of the studied MDRPs on SDG 3 in Egypt. The results of MDRPs performed on SDG 3 are in one line with the SDG 3 targets numbered from 3.1 to 3.8, and from 3.A to 3.D. (Table 2 and Figure 6(b)). On the other side, Figure 6(c) displays selective MDRPs focused on SDGs 4 for newest and recently developed educational systems, E-Learning process and E-testing process, and educational methodologies in Egyptian universities such as Ain Shams University (ASU), and Benha University (BU). The development of some educational hospitals are monitored and reported carefully to evaluate current progress of higher education development in educational hospitals sectors. As can be seen in Figure 6(c), the results of MDRPs performed on SDG 4 are in good agreement with the SDG 4 targets numbered from 4.1 to 4.7, and from 4.A to 4.C. (Table 2 and Figure 6(c)).

\subsection{Comparison between MDRPs on SDGs 6, 7 and Their Targets}

Figure 7(a) displays selective MDRPs focused on SDGs 6 for clean water and 
water treatment developing in different locations in Egypt such as Asyut Bridges, water desalination plant on the Red Sea or the Mediterranean Sea, water treatment plant in Al-Gabal El-Asfar zone north of Cairo, and pure water factory in

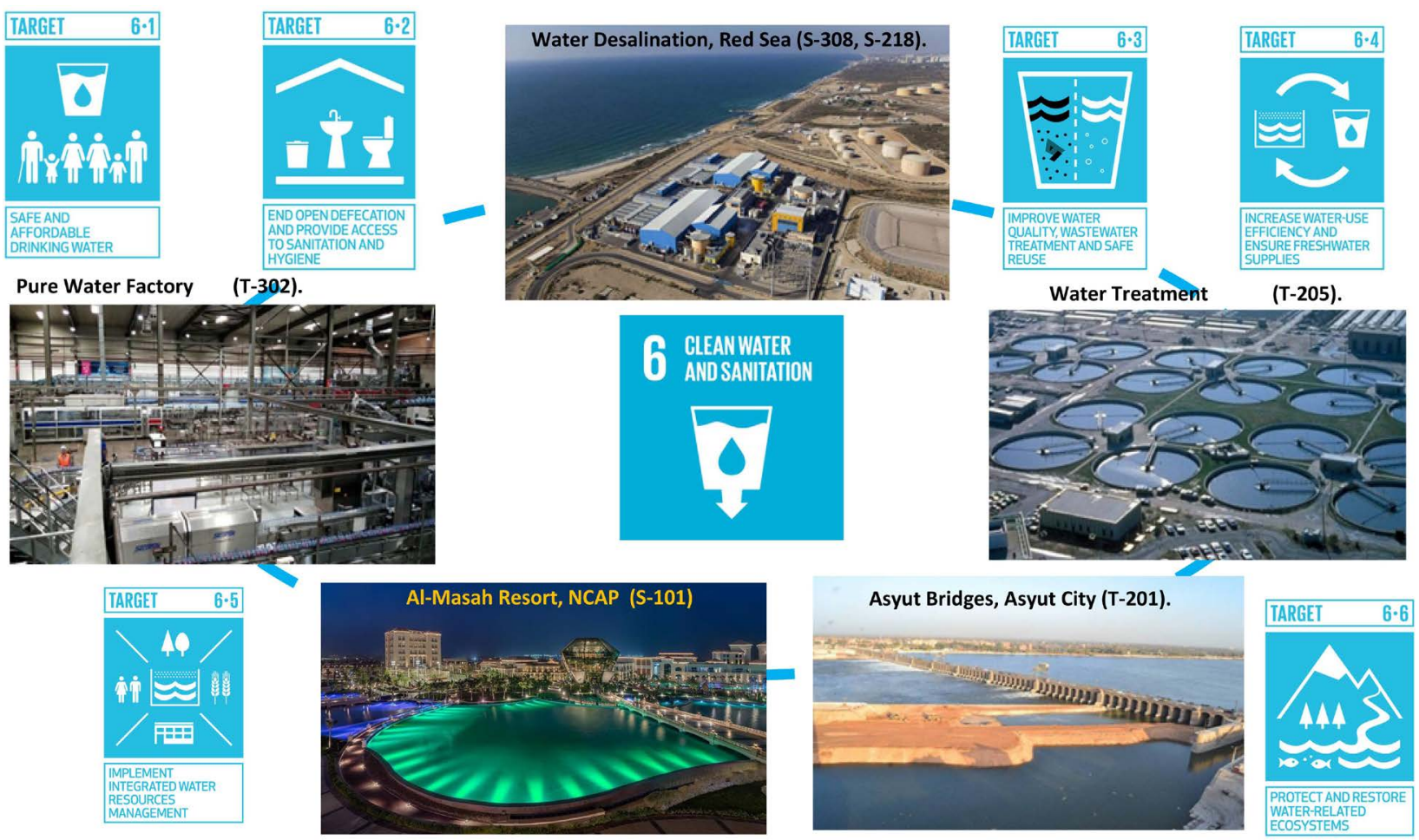

(a)
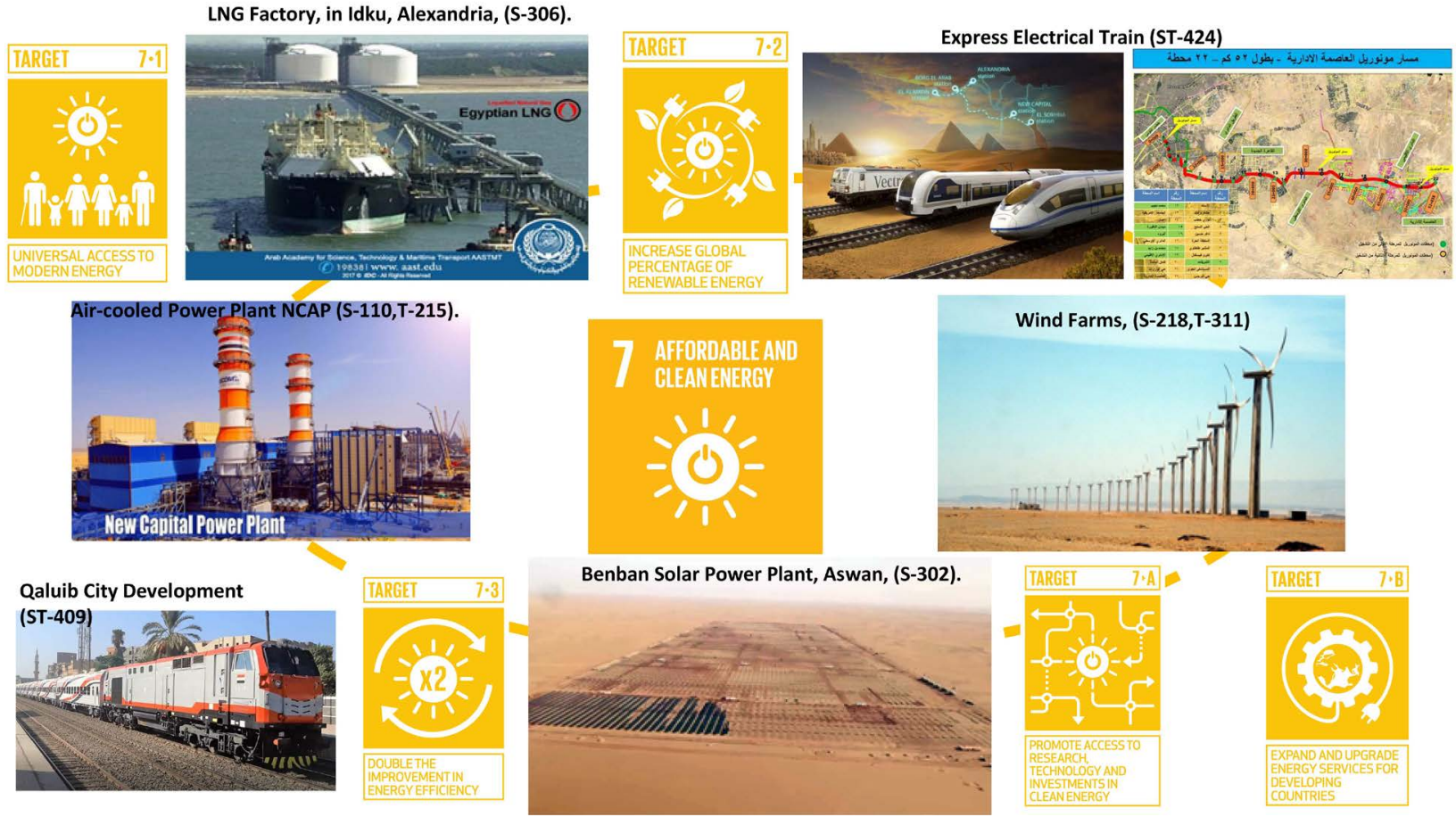

(b)

Figure 7. SDGs 6, and 7 targets and performed MDRPs. (a) SDG 6 and MDRPs on SDG 6 and (b) SDG 7 and MDRPs on SDG 7. 
Kafer Al-Arbeen zone, Benha City (See both Figure 3(b) and Figure 7(a)). As can be seen in Figure 7(a), the results of MDRPs focused on SDG 6 are in good agreement with the SDG 6 targets numbered from 6.1 to 6.6 (Table 2 and Figure 7(a)). Figure 7(b) depicts selective MDRPs focused on SDG 7 for renewable energy projects located in different zones in Egypt, such as wind energy and wind farms in the Zaafarana zone on the Red Sea coast at the east of Egypt, and solar energy and photovoltaic cells in Benban zone at west of Aswan. Two MDRPs subjected interest on natural gas refinery in the Mediterranean Sea in Dhoher gas field northeast of Alexandria, LNG industry and transportation in the two factories in Egypt, in Idku east of Alexandria and in Dumyat zone in north delta coast. The results of MDRPs focused on SDG 7 are in one line with the SDG 7 targets numbered from 7.1 to 7.3, 7.A and 7.B (Table 2 and Figure $7(b))$.

\subsection{Comparison between MDRPs on SDGs 9, 11 and Their Targets}

Several MDRPs focused on SDG 9 to validate the occupational health and safety for infrastructure and industry innovation in different locations in Egypt. Figure 8(a) illustrates selective MDRPs focused on SDG 9 such as the suspended bridge of Rod El-Farag Axis (by Arab Contractors Company), the newly developed pivoted tram in Alexandria, Heliopolis zone and Nasr City zone in east Cairo zones, by adding a large number of bridges as free intersections for main axes of Heliopolis and Nasr City zones, and the recently added extension for Cairo Metro Line 3 in Airport zone. The results of MDRPs focused on SDG 9 are in consistent with the SDG 9 targets numbered from 9.1 to 9.5, 9.A, 9.B, and 9.C (Table 3 and
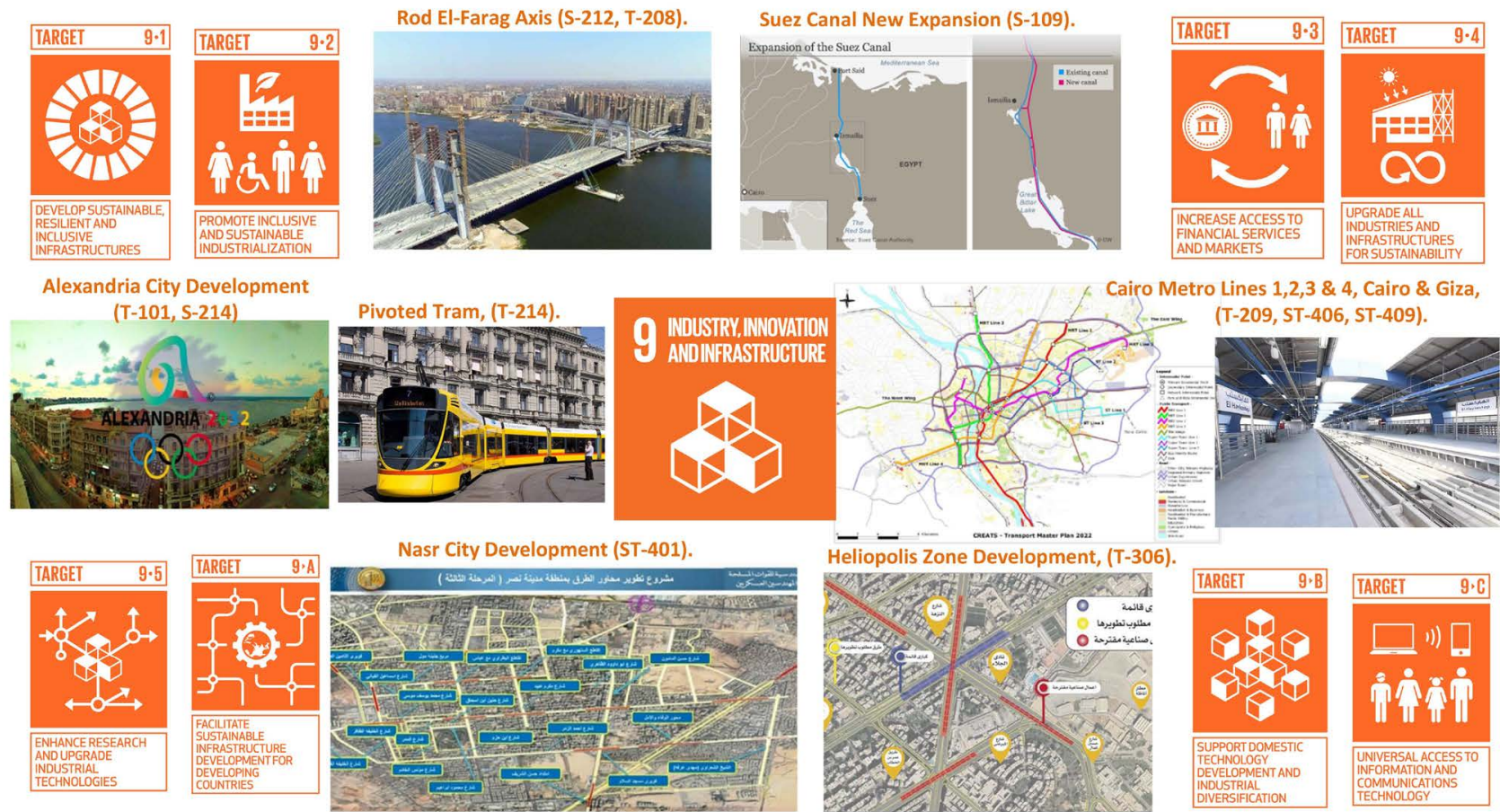

(a) 


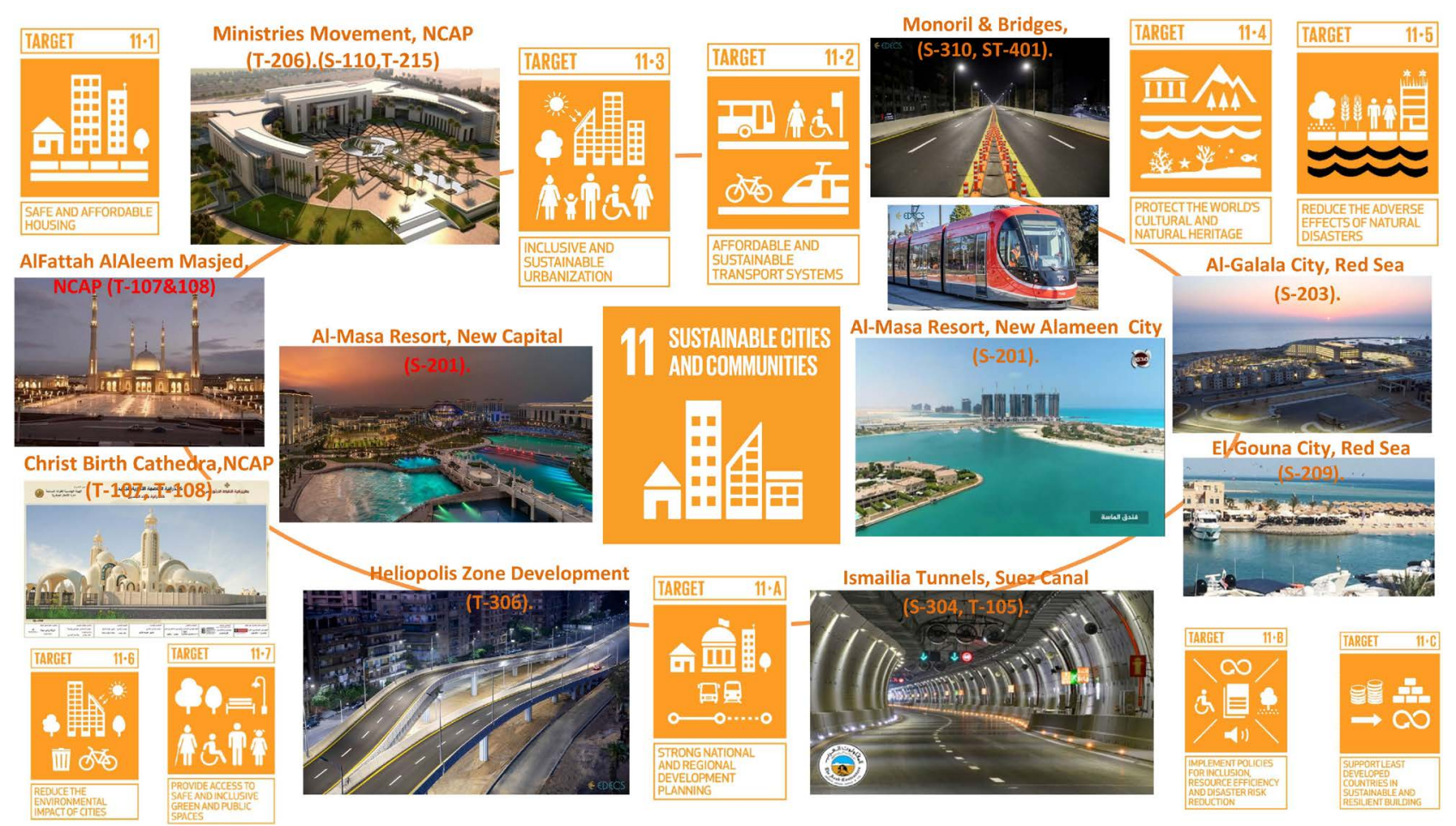

(b)

Figure 8. SDGs 9, and 11 targets and performed MDRPs. (A) SDG 9 and MDRPs on SDG 9 and (b) SDG 11 and MDRPs on SDG 11.

Figure 8(a)). Figure 8(b) displays selective MDRPs focused on SDGs 11 for new cities and communities in different locations in Egypt such as new capital projects and monorail, New Al-Alameen City, Al-Masah Hotel buildings in new capital, and new Al-Alameen city, Al-Galala city on the east coast of Egypt north Al-Sokhna city, El-Gouna city on the Red Sea coast, and the developed plot plan for ministries movement in new Capital (Figure 3(b), Figure 3(c) and Figure 8(b)). As can be seen in Figure 8(b), the results of MDRPs focused on SDG 11 are in good agreement with the SDG 11 targets numbered from 11.1 to 11.7, and 11.A-C, (Table 3 and Figure 8(b)).

\subsection{Effects of COVID-19 on MDRPs Orientation}

As discussed before in literature review, the effects of COVID-19 on most affected SDGs 3, 4, 6, and 7 are pronounced and recently investigated by several researches around the world. Table 4 depicts the MDRPs recently conducted during the Fall 2020. The selections of most of these MDRPs focus on the influence of the COVID-19 on the current projects and activities in Egypt, especially in the healthcare facilities, medical informatics, hybrid educational systems in both universities and schools, and precautionary measures should be taken by workers in construction projects and factories, passengers in transportation means, and prayers in praying areas in masjids and churches. As can be seen in Table 4, several MDRPs focused on SDG 3 to study field isolation hospital, hospitals 
Table 4. Symmetrical matrix for the case studies performed during extended current semester fall 2021.

\begin{tabular}{|c|c|c|c|c|c|c|c|c|c|}
\hline \multicolumn{2}{|r|}{$\begin{array}{c}\text { MEP Groups } \\
\text { ST-401 to ST-413 }\end{array}$} & \multirow{2}{*}{$\begin{array}{l}\text { Cairo, New } \\
\text { Cairo \& } \\
\text { Giza Zones }\end{array}$} & \multirow{2}{*}{$\begin{array}{c}\text { Port Said } \\
\text { \& Suez } \\
\text { Canal Zone }\end{array}$} & \multirow{2}{*}{$\begin{array}{l}\text { North } \\
\text { Delta }\end{array}$} & \multirow{2}{*}{$\begin{array}{l}\text { Alexandria } \\
\text { City \& } \\
\text { North Coast }\end{array}$} & \multirow{2}{*}{$\begin{array}{l}\text { Red Sea } \\
\& \text { Sinai } \\
\text { Zones }\end{array}$} & \multirow{2}{*}{$\begin{array}{c}\text { Aswan City } \\
\text { \& Upper } \\
\text { Egypt }\end{array}$} & \multicolumn{2}{|c|}{$\begin{array}{c}\text { MEP Groups } \\
\text { ST-414 to ST-425 }\end{array}$} \\
\hline Code & Project Title & & & & & & & Project Title & Code \\
\hline ST-401 & Nasr City Development & $\begin{array}{l}\text { ST-401 } \\
\text { ST-414 }\end{array}$ & & & & & & $\begin{array}{l}\text { Art \& Culture } \\
\text { City in NCAP }\end{array}$ & ST-414 \\
\hline ST-402 & Solar Driven Hospitals & & & ST-415 & & & $\begin{array}{l}\text { ST-402 } \\
\text { ST-415 }\end{array}$ & $\begin{array}{c}\text { Education \& } \\
\text { Sports Activities }\end{array}$ & ST- 415 \\
\hline ST-403 & Field Isolation Hospitals & $\begin{array}{l}\text { ST- } 403 \\
\text { ST-416 }\end{array}$ & & & ST-416 & & & Isolation Hospitals & ST-416 \\
\hline ST-404 & Four Seasons Hotels \& Resorts & $\begin{array}{l}\text { ST-404 } \\
\text { ST-417 }\end{array}$ & & & ST-417 & & & $\begin{array}{l}\text { Hybrid Educational } \\
\text { in New Universities }\end{array}$ & ST-417 \\
\hline ST-405 & Robotics in Hospitals & & & ST-405 & ST-418 & & & $\begin{array}{l}\text { Waste Management } \\
\text { \& Recycle }\end{array}$ & ST- 418 \\
\hline ST-406 & Cairo Metro Line 3 & $\begin{array}{l}\text { ST-406 } \\
\text { ST-419 }\end{array}$ & & & ST-419 & & & $\begin{array}{c}\text { Hybrid Educational } \\
\text { Systems }\end{array}$ & ST-419 \\
\hline ST-407 & High Rise Buildings in NCAP & $\begin{array}{l}\text { ST- } 407 \\
\text { ST- } 420\end{array}$ & & & & & & $\begin{array}{c}500500 \text { Cancer } \\
\text { Hospital }\end{array}$ & ST -420 \\
\hline ST- 408 & New Alameen University & & ST-421 & & $\begin{array}{l}\text { ST-408 } \\
\text { ST-421 }\end{array}$ & & -421 & $\begin{array}{l}\text { Precautionary in } \\
\text { Praying Areas }\end{array}$ & ST- 421 \\
\hline ST-409 & Qaluib City Development & & & ST-409 & ST-422 & & & $\begin{array}{l}\text { Steel Factories and } \\
\text { Industries }\end{array}$ & ST- 422 \\
\hline ST- -410 & Vaccine Transportation & & & & $\begin{array}{l}\Gamma-410 \\
\Gamma-423\end{array}$ & & & $\begin{array}{l}\text { IT \& COVID-19 } \\
\text { Relationship }\end{array}$ & ST-423 \\
\hline ST-411 & Olympic City in NCAP & $\begin{array}{l}\text { ST-411 } \\
\text { ST-424 }\end{array}$ & & & ST- 424 & ST-424 & & $\begin{array}{c}\text { Express Electrical } \\
\text { Train }\end{array}$ & ST- -424 \\
\hline ST-412 & Newborn Hospitals & ST-425 & & ST-412 & & & & $\begin{array}{l}\text { IT \& COVID-19 } \\
\text { Relationship }\end{array}$ & ST- 425 \\
\hline ST-413 & Juices \& Soft Drink Industries & & & ST-413 & & & & & \\
\hline
\end{tabular}

driven by solar energy, isolation hospital using robotics and automation, educational hospital transformation to isolation hospitals, newborns incubators and infants' hospitals, IT and COVID-19 relationships, importance of medical informatics and vaccine development, transportation and storage. Figure 9(a) displays some selective of these MDRPs focus on SDG 3 after COVID-19. In addition, one MDRP focuses on medical wastes recycling. On the other side, Figure 9(b) displays some selective of these MDRPs focus on SDGs 4, 9, and 11 after COVID-19. Several MDRPs carefully focus on the effects and methodologies of hybrid educational systems, either in universities or in schools in Egypt (Figure 9(b)). Only one MDRP focuses on SDG 2 for production process of juices and soft drinks inside factories. Figure 9(b) depicts some selective MDRPs focus on SDG 9 to study infrastructure for current projects infrastructure and steel industries (Table 4 and Figure 8(a)). Similarly, for SDG 11, several MDRPs focus on current projects conducted on in new cities such as Nasr City development and monorail from Nasr city to new Capital (Figure 8(b) and Figure 9(b)), and new 
stations of Cairo metro line 3 (Table 4 and Figure 8(b)). Finally, several MDRPs carefully focus on precautionary measures inside praying areas either in Masjids or in churches, precautionary measures inside transportation such as Cairo Metro

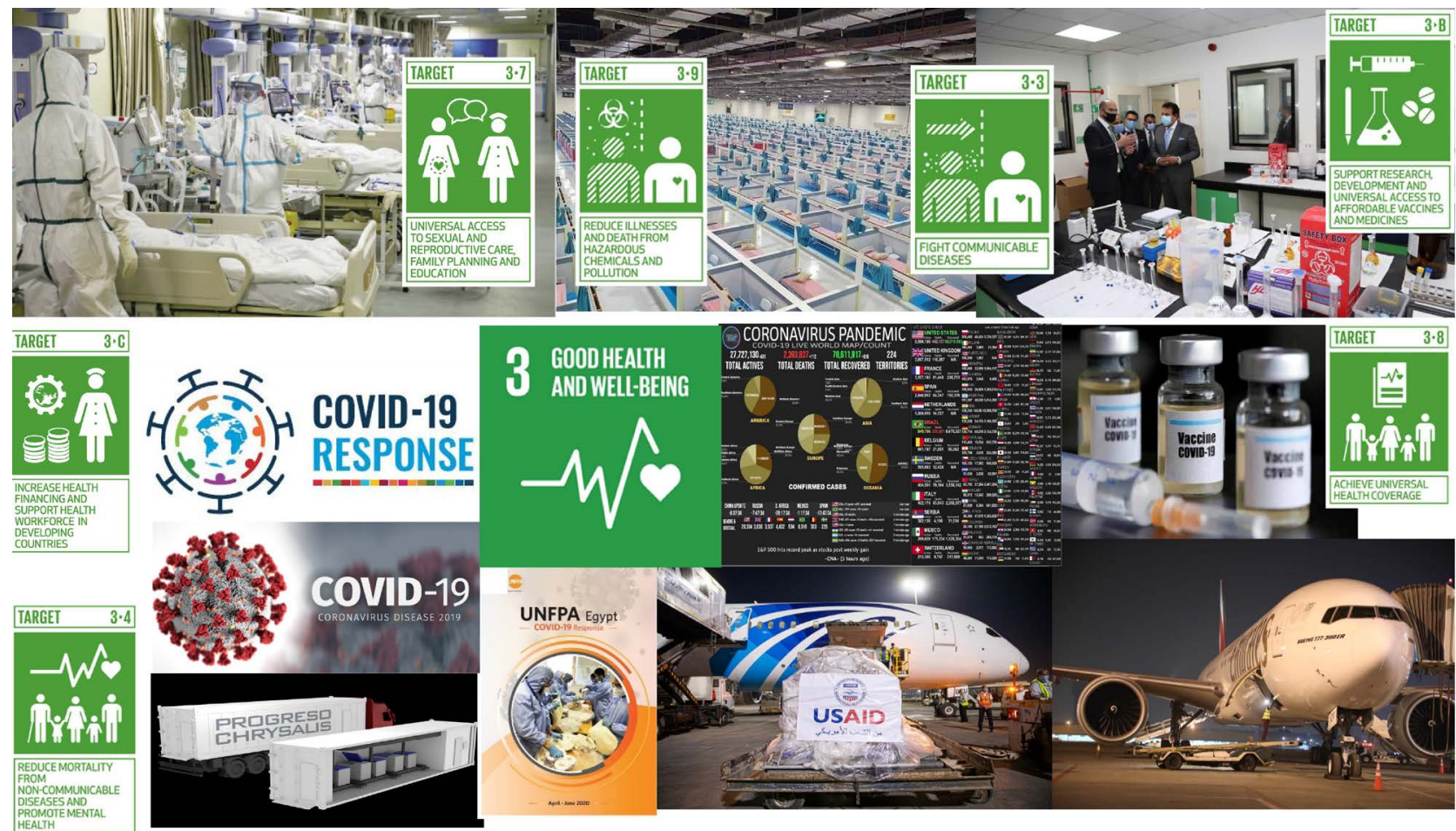

(a)

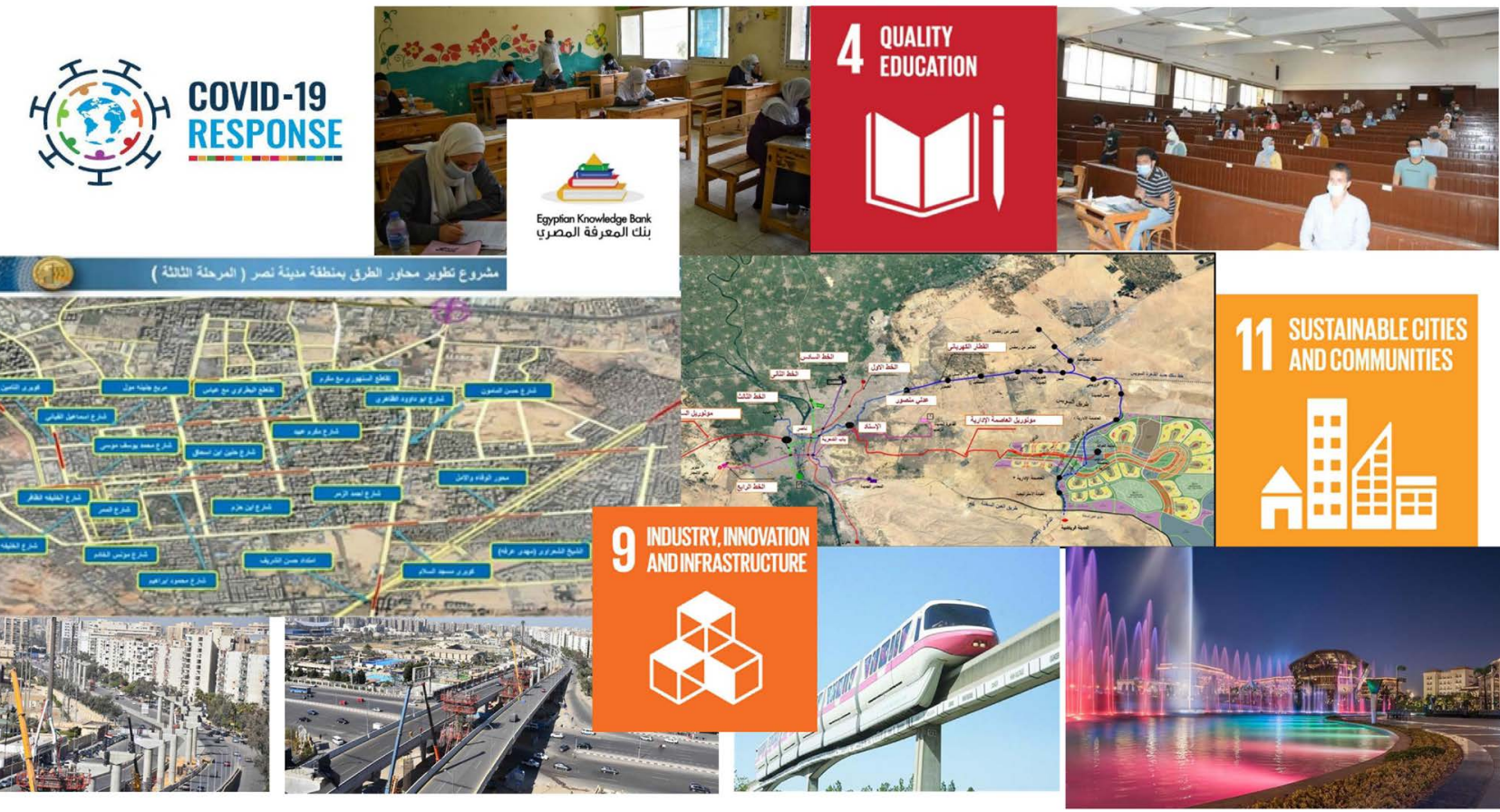

(b)

Figure 9. Covid-19 response in Egypt (a) For SDG 3 and MDRPs on SDG 3 and COVID-19 Response and (b) MDRPs on precautionary measures for SDGs 4, 9, 11 and 16 under COVID-10 response. 
lines 1, 2 and line 3, precautionary measures in hotels buildings and resorts, precautionary measures in stadiums, sporting clubs and sports activities, and precautionary measures in construction projects, and in steel industries.

The findings from depicted from Table 4 confirm the comparison between these recorded percentages, indicated before on Figure 5(a), Figure 5(b) and Figure 5(c), for SDGs 3, 4, 9, and 11 by $9 \%$ for SDG 3, 5.4\% for SDG 4, $4.5 \%$ for both SDGs 9 and 11. On the other side, Table 4 confirms the recorded fixed percentages recorded for SDG 6 at $5.41 \%$, for SDG 7 at $10.81 \%$ and for 12 at $1.8 \%$.

Figure 9(a) demonstrates Egypt response to rapidly prepare systems and equipment for field hospitals and vaccine development and transportation under the COVID-19 by demonstrating selective MDRPs focused on this SDG 3 and COVID-19 response. Figure 9(a) displays both cutaways in isolation hospital and the field isolation hospital which rapidly constructed similar to that one in China to alleviate the COVID-19 pandemic and to reduce the rate of mortality in Egypt. Figure 9(a) depicts the importance UNFPA in Egypt to report and record all medical informatics in the line with the globe around the world countries under COVID-19 pandemic. Figure 9(a) illustrates the COVID-19 vaccine development, transportation, and storage as per the results collected from one of the recent MDRPs. Figure 9(b) demonstrates the precautionary measures to fulfill COVID-19 response in Egypt for selective MDRPs on SDGs 4, 9, and 11 to summarize the findings using pictorial and graphical methods. Figure 9(b) shows using both research based and face to face learning methods to chive the targets of SDG 4 in Egypt during the COVID-19 pandemic. Figure 9(b) illustrates the transportation and infrastructure projects lunched recently in 2020 in Egypt as applications on SDG 9 such as Cairo Metro line 3 - stage 4 at east Cairo zone, pre-lunched project of Electric Express Train (EET) from Al-Shokhna to Al-Almeen city, and new Capital monorail involved in Nacer city development projects. Figure 9(b) indicates development agenda in Egypt on SDG 9 and 11 by displaying both plot plans for New Capital new urban planning and Nacer city development plan, which are direct applications on new cities projects, SDG 11 and infrastructure projects SDG 9, in Egypt respectively. This finding report and record all economic, social and environmental impacts of these new studies in Egypt under COVID-19 pandemic. Figure 9(b) confirms that Egypt vision 2030 is in the line with the globe around the world countries.

Figure 10 displays all the graphically designed cover pages for 25 MDRPs recently prepared and submitted electronically by students, to fulfill their occupational health and safety curriculum. Most of the selected background colors are in good agreement with the SDGs logos and colors (Figure 1 and Figure 10). Figure 10 graphically summarizes the 25 MDRPs listed in Table 4 which are investigated after the COVID-19 pandemic starts and under its impacts on most SDGs, such as 3, 4, 6, 7, 9 and 11 in Egypt currently hot spots and main concerns. Figure 10 confirms that Egypt vision 2030 is in good agreement with 

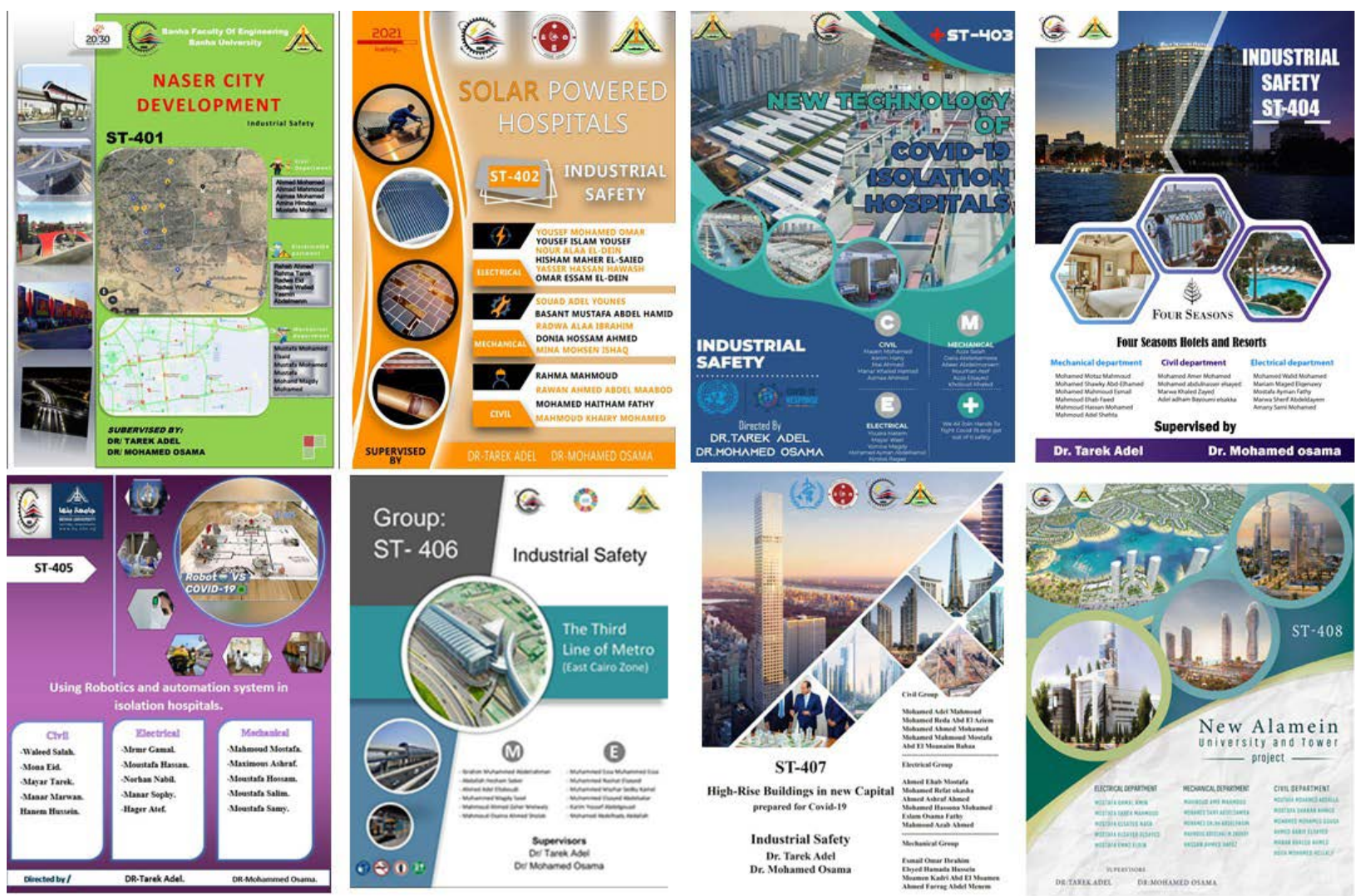

(a)
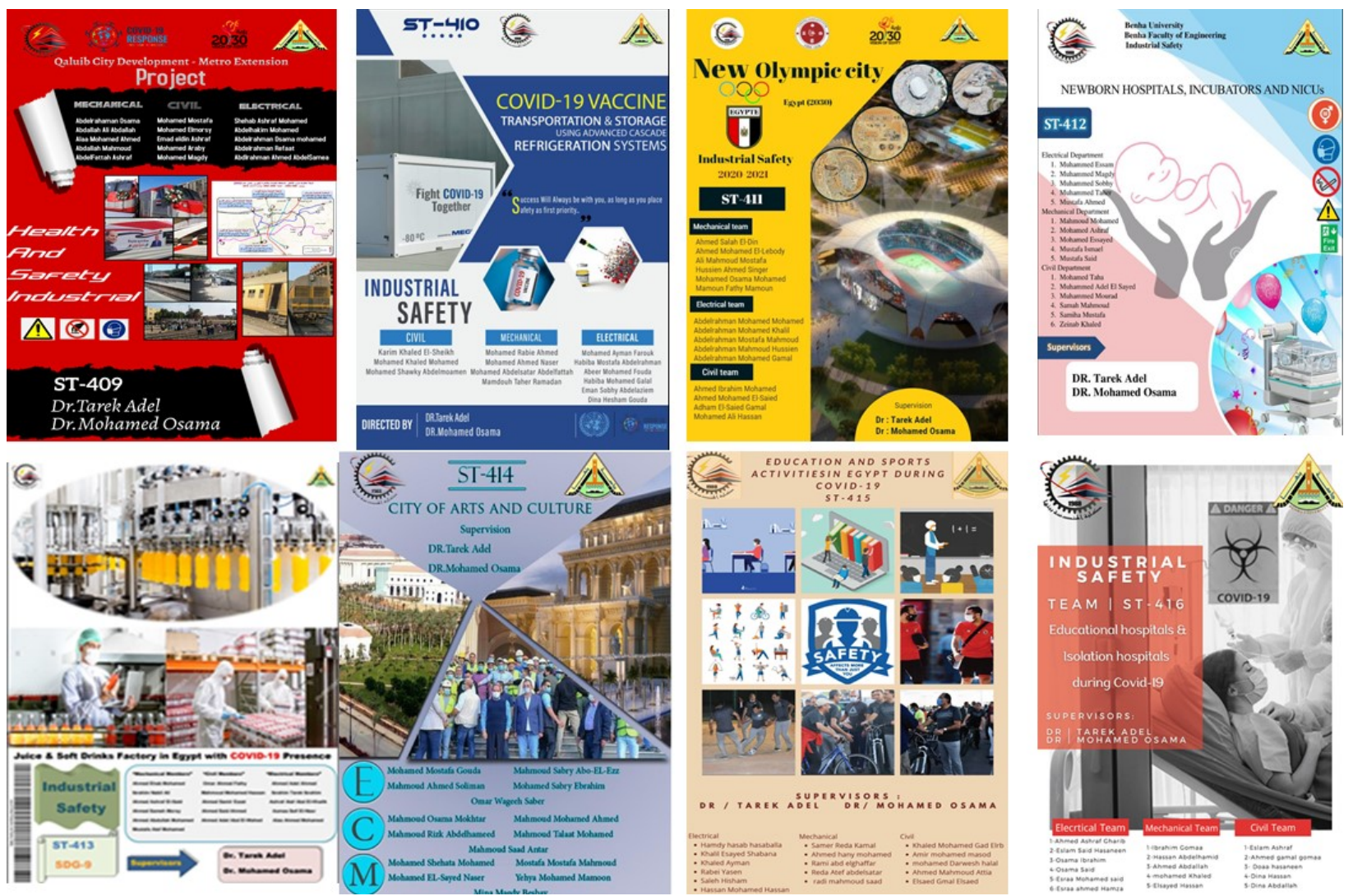

(b) 

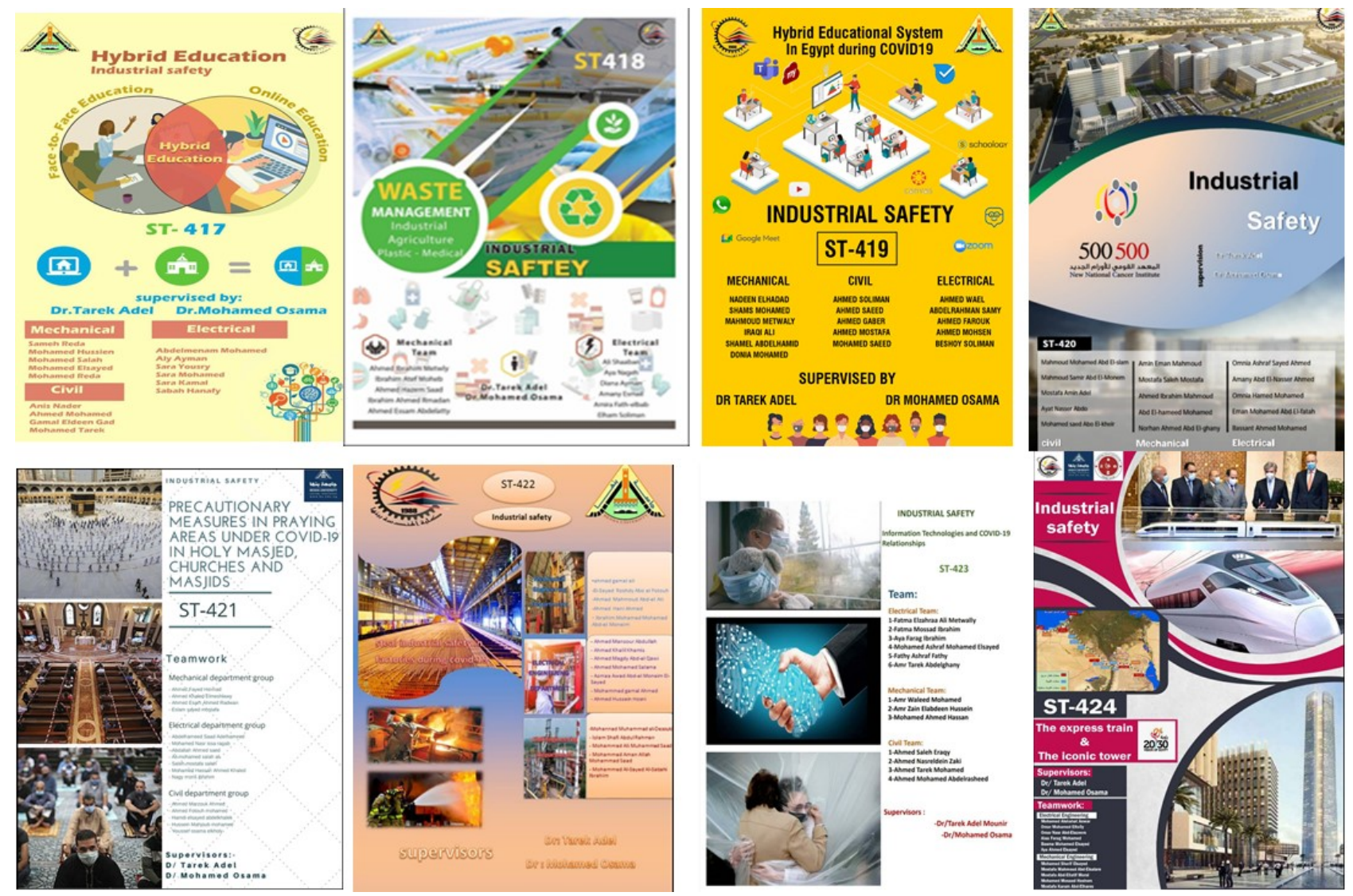

(c)

Figure 10. Egypt response to alleviate COVID-19 illustrated on cover pages of MDRPs ST-400s. (a) ST-401 to ST-408, (b) ST-409 to ST-416 and (c) ST-417 to ST-424.

those Agendas of other countries. Finally, this discussion section of the results of 125 MDRPs summaries and confirms on the validation of research objectives on using research based method in hybrid education for Engineering in Egypt, with and without SDGs interlink, and before and after the COVID-19 impacts. The overall results indicate that SDG 4 helps engineering education to fulfill SDG 3 requirements either before the COVID-19 or under its impacts. The results summarize that SDG 6 and SDG 7 help the fulfill requirements of both SDGs 9 and 11 in Egypt as per the 2030 agenda.

\section{Concluding Remarks and Recommendations}

The proposed objective is achieved, whose purpose is to assess and evaluate the using current research methodologies in both learning and teaching processes such as 1) grouping students in multidisciplinary groups, 2) research based case studies, and 3) hybrid education system. The results validate the performance of MDRPs conducted under author contributions, supervision and technical guidance, on the SDGs relating to research goals by interlinking them cohesively and also by using pictorial communication, as an attractive trend very well designed and presented. This article outlines the successful approaches to interlink be- 
tween the SDGs before and after the COVID-19 using the carefully selected curriculum of industrial safety studied in one of the Egyptian universities. The findings represent an integrity between all these used methodologies to involve sustainable development goals SDGs 3, 4, 6, 7, 9, and 11 into the occupation health and safety curriculum and give promising limitations to be applied in several engineering curriculums in future work by professors to raise the awareness among students in Egyptian universities using Egypt vision 2030. It should be clear also that these investigations can be reproduced similarly in any of other developed and developing countries which have agenda complies with the 2030 Agenda. This current article also concludes the following conclusions.

- The literature overview indicates the possibility to assess the indictors of SDGs using different technique and approaches such as LCA, MFA, CBA to evaluate the progress of each SDGs under investigation.

- The 125 MDRPs validate and confirm the successful method of students grouping in multidisciplinary groups to focus on SDG using occupational health and safety curriculum.

- The pronounced effectiveness of interlinking between higher education development and the SDGs in Egypt among both staff members, and engineering students.

- The results are very sensitive to the COVID-19 impacts, which are very important factors on these occupational cross-sectional studies.

- New and advanced educational methods shall be used to maximize the benefits of hybrid education.

- Importance on occupational health and safety in hospitals buildings during the COVID-19 and any expected future pandemics.

Finally, the recommendations for future work are to study carefully the impacts of the COVID-19 pandemic on the economy and the direct and indirect impacts of it on the economical SDGs such as SDG 1 and SDG 10. The impacts on environmental SDGs 13,14, and 15 should be covered in future environmental sustainability studies and compare between before and after the COVID-19 pandemic in different countries, such as the currently performed study in Egypt. Several researches are highly recommended in future work to focus the attention on each future publications by author, specialists and analysts on each of the SDGs $3,4,6,7,9$, and 11 in separate articles to be extracted from the current frame of work.

\section{Acknowledgements}

The author acknowledges all students in Benha Faculty of Engineering at Benha University who can be considered as major partners by their hard work and dedication. Acknowledgement is also given for the graphic contributions, suggestions, and comments to prepare the cross-sectional studies reported in this article after four academic years in studying the curriculum of occupational health and safety. 


\section{Conflicts of Interest}

The author declares no conflicts of interest regarding the publication of this paper.

\section{References}

Acuti, D., Bellucci, M., \& Manetti, G. (2020). Company Disclosures Concerning the Resilience of Cities from the Sustainable Development Goals (SDGs) Perspective. Cities, 99, Article ID: 102608. https://doi.org/10.1016/j.cities.2020.102608

Adenle, A. A. (2020). Assessment of Solar Energy Technologies in Africa-Opportunities and Challenges in Meeting the 2030 Agenda and Sustainable Development Goals. Energy Policy, 137, Article ID: 111180. https://doi.org/10.1016/j.enpol.2019.111180

Alawneh, R., Ghazali, F., Ali, H., \& Sadullah, A. F. (2019). A Novel Framework for Integrating United Nations Sustainable Development Goals into Sustainable Non-Residential Building Assessment and Management in Jordan. Sustainable Cities and Society, 49, Article ID: 101612. https://doi.org/10.1016/j.scs.2019.101612

Asi, Y. M., \& Williams, C. (2018). The Role of Digital Health in Making Progress toward Sustainable Development Goal (SDG) 3 in Conflict-Affected Populations. International Journal of Medical Informatics, 114, 114-120. https://doi.org/10.1016/j.ijmedinf.2017.11.003

Athar, M., Shariff, A. M., Buang, A., Shaikh, M. S., \& See, T. L. (2019). Inherent Safety for Sustainable Process Design of Process Piping at the Preliminary Design Stage. Journal of Cleaner Production, 209, 1307-1318. https://doi.org/10.1016/j.jclepro.2018.10.281

Aziz, S., \& Chowdhury, S. A. (2021). Performance Evaluation of Solar Mini-Grids in Bangladesh: A Two-Stage Data Envelopment Analysis. Cleaner Environmental Systems, 2, Article ID: 100003. https://doi.org/10.1016/j.cesys.2020.100003

Benevenuto, R., \& Caulfield, B. (2019). Poverty and Transport in the Global South: An Overview. Transport Policy, 79, 115-124. https://doi.org/10.1016/j.tranpol.2019.04.018

Biemans, H., \& Siderius, C. (2019). Advances in Global Hydrology-Crop Modelling to Support the UN's Sustainable Development Goals in South Asia. Current Opinion in Environmental Sustainability, 40, 108-116. https://doi.org/10.1016/j.cosust.2019.10.005

Cernev, T., \& Fenner, R. (2020). The Importance of Achieving Foundational Sustainable Development Goals in Reducing Global Risk. Futures, 115, Article ID: 102492.

https://doi.org/10.1016/j.futures.2019.102492

Cole, M. J., \& Broadhurst, J. L. (2021). Measuring the Sustainable Development Goals (SDGs) in Mining Host Communities: A South African Case Study. The Extractive Industries and Society, 8, 233-243. https://doi.org/10.1016/j.exis.2020.11.012

Cormier, R., \& Elliott, M. (2017). SMART Marine Goals, Targets and Management-Is SDG 14 Operational or Aspirational, Is "Life below Water" Sinking or Swimming? Marine Pollution Bulletin, 123, 28-33. https://doi.org/10.1016/j.marpolbul.2017.07.060

Costantini, M., \& Bacenetti, J. (2021). Soybean and Maize Cultivation in South America: Environmental Comparison of Different Cropping Systems. Cleaner Environmental Systems, 2, Article ID: 100017. https://doi.org/10.1016/j.cesys.2021.100017

Dada, O., \& Mbohwa, C. (2018). Energy from Waste: A Possible Way of Meeting Goal 7 of the Sustainable Development Goals. Materials Today: Proceedings, 5, 10577-10584. https://doi.org/10.1016/j.matpr.2017.12.390

Delre, A., ten Hoeve, M., \& Scheutz, C. (2019). Site-Specific Carbon Footprints of Scandinavian Wastewater Treatment Plants, Using the Life Cycle Assessment Approach. Journal of Cleaner Production, 211, 1001-1014.

https://doi.org/10.1016/j.jclepro.2018.11.200 
Dhahri, S., \& Omri, A. (2020). Foreign Capital towards SDGs 1 \& 2-Ending Poverty and Hunger: The Role of Agricultural Production. Structural Change and Economic Dynamics, 53, 208-221. https://doi.org/10.1016/j.strueco.2020.02.004

Djekic, I., Nikolić, A., Uzunović, M., Marijke, A., Liu, A., Han, J., Brnčić, M., Knežević, N., Papademas, P., Lemoniati, K., Witte, F., Terjung, N., Papageorgiou, M., Zinoviadou, K. G., Dalle Zotte, A., Pellattiero, E., Sołowiej, B. G., Guiné, R. P. F., Correia, P., Sirbu, A., Vasilescu, L., Semenova, A. A., Kuznetsova, O. A., Vrabič Brodnjak, U., Pateiro, M., Lorenzo, J. M., Getya, A., Kodak, T., \& Tomasevic, I. (2021). Covid-19 Pandemic Effects on Food Safety-Multi-Country Survey Study. Food Control, 122, Article ID: 107800. https://doi.org/10.1016/j.foodcont.2020.107800

Du, Z. X., Lai, X. D., Long, W. J., \& Gao, L. L. (2020). The Short- and Long-Term Impacts of the COVID-19 Pandemic on Family Farms in China-Evidence from a Survey of 2324 Farms. Journal of Integrative Agriculture, 19, 2877-2890. https://doi.org/10.1016/S2095-3119(20)63390-1

Elsheikh, A. H., Saba, A. I., Elaziz, M. A., Lu, S., Shanmugan, S., Muthuramalingam, T., Kumar, R., Mosleh, A. O., Essa, F. A., \& Shehabeldeen, T. A. (2021). Deep Learning-Based Forecasting Model for COVID-19 Outbreak in Saudi Arabia. Process Safety and Environmental Protection, 149, 223-233. https://doi.org/10.1016/j.psep.2020.10.048

Esmaeilian, B., Rust, M., Gopalakrishnan, P. K., \& Behdad, S. (2018). Use of Citizen Science to Improve Student Experience in Engineering Design, Manufacturing and Sustainability Education. Procedia Manufacturing, 26, 1361-1368. https://doi.org/10.1016/j.promfg.2018.07.124

Farkas, K., Hillary, L. S., Malham, S. K., McDonald, J. E., \& Jones, D. L. (2020). Wastewater and Public Health: The Potential of Wastewater Surveillance for Monitoring COVID-19. Current Opinion in Environmental Science \& Health, 17, 14-20. https://doi.org/10.1016/j.coesh.2020.06.001

Filho, L. W., Shiel, C., Paço, A., Mifsud, M., Ávila, L. V., Brandli, L. L., Molthan-Hill, P., Pace, P., Azeiteiro, U. M., Vargas, V. R., \& Caeiro, S. (2019). Sustainable Development Goals and Sustainability Teaching at Universities: Falling behind or Getting Ahead of the Pack? Journal of Cleaner Production, 232, 285-294.

https://doi.org/10.1016/j.jclepro.2019.05.309

Giannetti, B. F., Agostinho, F., Eras, J. J. C., Yang, Z., \& Almeida, C. M. V. B. (2020). Cleaner Production for Achieving the Sustainable Development Goals. Journal of Cleaner Production, 271, Article ID: 122127. https://doi.org/10.1016/j.jclepro.2020.122127

Haq, H., Petri, V., Mesquita, L., Kumpulainen, L., \& Niemi, S. (2021). An Application of Seasonal Borehole Thermal Energy System in Finland. Cleaner Engineering and Technology, 2, Article ID: 100048. https://doi.org/10.1016/j.clet.2021.100048

Heck, V., Hoff, H., Wirsenius, S., Meyer, C., \& Kreft, H. (2018). Land Use Options for Staying within the Planetary Boundaries-Synergies and Trade-Offs between Global and Local Sustainability Goals. Global Environmental Change, 49, 73-84. https://doi.org/10.1016/j.gloenvcha.2018.02.004

Herrmann, B., \& Rundshagen, V. (2020). Paradigm Shift to Implement SDG 2 (End Hunger): A Humanistic Management Lens on the Education of Future Leaders. International Journal of Management in Education, 18, Article ID: 100368. https://doi.org/10.1016/j.ijme.2020.100368

Hsu, W.-T., Domenech, T., \& McDowall, W. (2021). How Circular Are Plastics in the EU? MFA of Plastics in the EU and Pathways to Circularity. Cleaner Environmental 
Systems, 2, Article ID: 100004. https://doi.org/10.1016/j.cesys.2020.100004

Huyghe, W., Hernández-Pacheco Algaba, M., van Leeuwen, K., Koop, S., \& Eisenreich, S. (2021). Assessment of the Urban Water Cycle in Antwerp (BE): The City Blueprint Approach (CBA). Cleaner Environmental Systems, 2, Article ID: 100011. https://doi.org/10.1016/j.cesys.2021.100011

Killian, S., Lannon, J., Murray, L., Avram, G., Giralt, M., \& O’Riordan, S. (2019). Social Media for Social Good: Student Engagement for the SDGs. International Journal of Management in Education, 17, Article ID: 100307.

https://doi.org/10.1016/j.ijme.2019.100307

Kynčlová, P., Upadhyaya, S., \& Nice, T. (2020). Composite Index as a Measure on Achieving Sustainable Development Goal 9 (SDG-9) Industry-Related Targets: The SDG-9 Index. Applied Energy, 265, Article ID: 114755.

https://doi.org/10.1016/j.apenergy.2020.114755

Lee, K. H., Noh, J., \& Khim, J. S. (2020). The Blue Economy and the United Nations' Sustainable Development Goals: Challenges and Opportunities. Environment International, 137, Article ID: 105528. https://doi.org/10.1016/j.envint.2020.105528

Lekomo, Y. K., Ekengoue, C. M., Douola, A., Lele, R. F., Suh, G. C., Obiri, S., \& Dongmo, A. K. (2021). Assessing Impacts of Sand Mining on Water Quality in Toutsang Locality and Design of Waste Water Purification System. Cleaner Engineering and Technology, 2, Article ID: 100045. https://doi.org/10.1016/j.clet.2021.100045

Lima, P. M., Morais, M. F., Constantino, M. A., Paulo, P. L., \& Filho, F. J. M. C. (2021). Environmental Assessment of Waste Handling in Rural Brazil: Improvements towards Circular Economy. Cleaner Environmental Systems, 2, Article ID: 100013. https://doi.org/10.1016/j.cesys.2021.100013

Lu, M. T., Tsai, J. F., Shen, S. P., Lin, M. H., \& Hu, Y. C. (2020). Estimating Sustainable Development Performance in the Electrical Wire and Cable Industry: Applying the Integrated Fuzzy MADM Approach. Journal of Cleaner Production, 277, Article ID: 122440. https://doi.org/10.1016/j.jclepro.2020.122440

Maji, I. K., \& Adamu, S. (2021). The Impact of Renewable Energy Consumption on Sectoral Environmental Quality in Nigeria. Cleaner Environmental Systems, 2, Article ID: 100009. https://doi.org/10.1016/j.cesys.2021.100009

Mao, Z., Xue, X., Tian, H., \& Michael, A. U. (2019). How Will China Realize SDG 14 by 2030?-A Case Study of an Institutional Approach to Achieve Proper Control of Coastal Water Pollution. Journal of Environmental Management, 230, 53-62. https://doi.org/10.1016/j.jenvman.2018.09.028

Marshall, K. (2018). Global Education Challenges: Exploring Religious Dimensions. International Journal of Educational Development, 62, 184-191. https://doi.org/10.1016/j.ijedudev.2018.04.005

Mishra, L., Gupta, T., \& Shree, A. (2020). Online Teaching-Learning in Higher Education during Lockdown Period of COVID-19 Pandemic. The International Journal of Educational Research Open, 1, Article ID: 100012. https://doi.org/10.1016/j.ijedro.2020.100012

Monteiro, N. B. R., da Silva, E. A., \& Moita Neto, J. M. (2019). Sustainable Development Goals in Mining. Journal of Cleaner Production, 228, 509-520. https://doi.org/10.1016/j.jclepro.2019.04.332

Moyer, J. D., \& Hedden, S. (2020). Are We on the Right Path to Achieve the Sustainable Development Goals? World Development, 127, Article ID: 104749. https://doi.org/10.1016/j.worlddev.2019.104749

Nazir, M. S., Ali, N., Bilal, M., \& Iqbal, H. M. N. (2020). Potential Environmental Impacts 
of Wind Energy Development: A Global Perspective. Current Opinion in Environmental Science \& Health, 13, 85-90. https://doi.org/10.1016/j.coesh.2020.01.002

Nikkhah, A., \& Van Haute, S. (2020). Energy Flow Modeling and Optimization Trends in Food Supply Chain: A Mini Review. Current Opinion in Environmental Science \& Health, 13, 16-22. https://doi.org/10.1016/j.coesh.2019.10.001

O, N. C., \& Kim, H. (2019). Towards the $2{ }^{\circ} \mathrm{C}$ Goal: Achieving Sustainable Development Goal (SDG) 7 in DPR Korea. Resources, Conservation \& Recycling, 150, Article ID: 104412. https://doi.org/10.1016/j.resconrec.2019.104412

O’Riordan, T. J. C. (2018). UN Sustainable Development Goals: How Can Sustainable/Green Chemistry Contribute? The View from the Agrochemical Industry. Current Opinion in Green and Sustainable Chemistry, 13, 158-163. https://doi.org/10.1016/j.cogsc.2018.06.014

Omer, M. A. B., \& Noguchi, T. (2020). A Conceptual Framework for Understanding the Contribution of Building Materials in the Achievement of Sustainable Development Goals (SDGs). Sustainable Cities and Society, 52, Article ID: 101869. https://doi.org/10.1016/j.scs.2019.101869

Parnell, S. (2016). Defining a Global Urban Development Agenda. World Development, 78, 529-540. https://doi.org/10.1016/j.worlddev.2015.10.028

Perez-Foguet, A., \& Lazzarini, B. (2019). Continuing Professional Education in Engineering Faculties: Transversal Integration of Sustainable Human Development in Basic Engineering Sciences Courses. Journal of Cleaner Production, 218, 772-781. https://doi.org/10.1016/j.jclepro.2019.02.054

Postigo, C., \& Richardson, S. (2019). Editorial Overview: Drinking Water Contaminants. Current Opinion in Environmental Science \& Health, 7, 5-7. https://doi.org/10.1016/j.coesh.2019.03.001

Priyadarshini, P., \& Abhilash, P. C. (2020). From Piecemeal to Holistic: Introducing Sustainability Science in Indian Universities to Attain UN-Sustainable Development Goals. Journal of Cleaner Production, 247, Article ID: 119133. https://doi.org/10.1016/j.jclepro.2019.119133

Requejo-Castro, D., Giné-Garriga, R., \& Pérez-Foguet, A. (2020). Data-Driven Bayesian Network Modelling to Explore the Relationships between SDG 6 and the 2030 Agenda. Science of the Total Environment, 710, Article ID: 136014. https://doi.org/10.1016/j.scitotenv.2019.136014

Reyes, J. P., San-José, J. T., Cuadrado, J., \& Sancibrian, R. (2014). Health \& Safety Criteria for Determining the Sustainable Value of Construction Projects. Safety Science, 62, 221-232. https://doi.org/10.1016/j.ssci.2013.08.023

Rezaian, S., \& Jozi, S. A. (2012). Health-Safety and Environmental Risk Assessment of Refineries Using of Multi Criteria Decision Making Method. APCBEE Procedia, 3, 235-238. https://doi.org/10.1016/j.apcbee.2012.06.075

Rowan, N. J., \& Moral, R. A. (2021). Disposable Face Masks and Reusable Face Coverings as Non-Pharmaceutical Interventions (NPIs) to Prevent Transmission of SARS-CoV-2 Variants That Cause Coronavirus Disease (COVID-19): Role of New Sustainable NPI Design Innovations and Predictive Mathematic. Science of the Total Environment, 772, Article ID: 145530. https://doi.org/10.1016/j.scitotenv.2021.145530

Ruan, G., Wu, J., Zhong, H., Xia, Q., \& Xie, L. (2021). Quantitative Assessment of U.S. Bulk Power Systems and Market Operations during the COVID-19 Pandemic. Applied Energy, 286, Article ID: 116354. https://doi.org/10.1016/j.apenergy.2020.116354

Santika, W. G., Anisuzzaman, M., Bahri, P. A., Shafiullah, G. M., Rupf, G. V., \& Urmee, T. (2019). From Goals to Joules: A Quantitative Approach of Interlinkages between 
Energy and the Sustainable Development Goals. Energy Research \& Social Science, 50, 201-214. https://doi.org/10.1016/j.erss.2018.11.016

Solís, P., McCusker, B., Menkiti, N., Cowan, N., \& Blevins, C. (2018). Engaging Global Youth in Participatory Spatial Data Creation for the UN Sustainable Development Goals: The Case of Open Mapping for Malaria Prevention. Applied Geography, 98, 143-155. https://doi.org/10.1016/j.apgeog.2018.07.013

Tasdemir, C., \& Gazo, R. (2020). Integrating Sustainability into Higher Education Curriculum through a Transdisciplinary Perspective. Journal of Cleaner Production, 265, Article ID: 121759. https://doi.org/10.1016/j.jclepro.2020.121759

Union, E. (2020). Egypt COVID-19 Response and Recovery Interventions of 1-14. https://egypt.un.org/en/89430-egypt-covid-19-response-and-recovery-interventions-un ited-nations-egypt

Villalba, L., \& Useche, E. (2021). Methodological Approach for the Construction of Environmental Management Indicators in Universities. Cleaner Environmental Systems, 2, Article ID: 100016. https://doi.org/10.1016/j.cesys.2021.100016

Wang, B., \& Wu, C. (2020). Safety Informatics as a New, Promising and Sustainable Area of Safety Science in the Information Age. Journal of Cleaner Production, 252, Article ID: 119852. https://doi.org/10.1016/j.jclepro.2019.119852

Zhou, J. H., Han, F., Li, K., \& Wang, Y. (2020). Vegetable Production under COVID-19 Pandemic in China: An Analysis Based on the Data of 526 Households. Journal of Integrative Agriculture, 19, 2854-2865. https://doi.org/10.1016/S2095-3119(20)63366-4 